\title{
Pharmacologic Characterization of AMG8379, a Potent and Selective Small Molecule Sulfonamide Antagonist of the Voltage-Gated Sodium Channel Nav1.7回
}

\author{
Thomas J. Kornecook, Ruoyuan Yin, Stephen Altmann, ${ }^{1}$ Xuhai Be, Virginia Berry, \\ Christopher P. Ilch, Michael Jarosh, Danielle Johnson, Josie H. Lee, Sonya G. Lehto, \\ Joseph Ligutti, Dong Liu, Jason Luther, David Matson, Danny Ortuno, ${ }^{2}$ John Roberts, \\ Kristin Taborn, Jinti Wang, Matthew M. Weiss, Violeta Yu, Dawn X. D. Zhu, \\ Robert T. Fremeau, Jr., ${ }^{3}$ and Bryan D. Moyer \\ Department of Neuroscience (T.J.K., R.Y., S.A, C.P.I., M.J., D.J., J.H.L., S.G.L., J.Li., D.L., J.Lu., D.M., D.O., K.T., J.W., V.Y., \\ D.X.D.Z., R.T.F., B.D.M.), Department of Medicinal Chemistry (M.M.W.), and Department of Pharmacokinetics and Drug \\ Metabolism (X.B., V.B., J.R.), Amgen Inc., Cambridge, Massachusetts and Thousand Oaks, California \\ Received December 19, 2016; accepted May 3, 2017
}

\begin{abstract}
Potent and selective antagonists of the voltage-gated sodium channel $\mathrm{Na}_{\mathrm{v}} 1.7$ represent a promising avenue for the development of new chronic pain therapies. We generated a small molecule atropisomer quinolone sulfonamide antagonist AMG8379 and a less active enantiomer AMG8380. Here we show that AMG8379 potently blocks human $\mathrm{Na}_{\mathrm{v}} 1.7$ channels with an $\mathrm{IC}_{50}$ of $8.5 \mathrm{nM}$ and endogenous tetrodotoxin (TTX)sensitive sodium channels in dorsal root ganglion (DRG) neurons with an $\mathrm{IC}_{50}$ of $3.1 \mathrm{nM}$ in whole-cell patch clamp electrophysiology assays using a voltage protocol that interrogates channels in a partially inactivated state. AMG8379 was 100 - to 1000 -fold selective over other $\mathrm{Na}_{v}$ family members, including $\mathrm{Na}_{v} 1.4$ expressed in muscle and $\mathrm{Na}_{\mathrm{v}} 1.5$ expressed in the heart, as well as TTX-resistant $\mathrm{Na}_{v}$ channels in DRG neurons. Using an ex vivo mouse skin-nerve preparation, AMG8379 blocked mechanically
\end{abstract}

induced action potential firing in C-fibers in both a timedependent and dose-dependent manner. AMG8379 similarly reduced the frequency of thermally induced $\mathrm{C}$-fiber spiking, whereas AMG8380 affected neither mechanical nor thermal responses. In vivo target engagement of AMG8379 in mice was evaluated in multiple Nav1.7-dependent behavioral endpoints. AMG8379 dose-dependently inhibited intradermal histamineinduced scratching and intraplantar capsaicin-induced licking, and reversed UVB radiation skin burn-induced thermal hyperalgesia; notably, behavioral effects were not observed with AMG8380 at similar plasma exposure levels. AMG8379 is a potent and selective Nav1.7 inhibitor that blocks sodium current in heterologous cells as well as DRG neurons, inhibits action potential firing in peripheral nerve fibers, and exhibits pharmacodynamic effects in translatable models of both itch and pain.

\section{Introduction}

Chronic pain represents a critical unmet medical need that afflicts over 100 million Americans with an economic cost over $\$ 500$ billion (Institute of Medicine, 2011; Holmes, 2016). Despite the multi-billion dollar pain market in the major markets of the United States, Europe, and Japan, current available therapies lack robust efficacy, carry significant abuse potential, and/or suffer from low tolerability and safety;

This work was funded by Amgen, Inc.

${ }^{1}$ Current affiliation: Sanofi-Genzyme, Cambridge, Massachusetts.

${ }^{2}$ Current affiliation: Novartis Institutes for BioMedical Research Inc., Cambridge, Massachusetts.

${ }^{3}$ Current affiliation: NeuroRx Consulting, Cambridge, Massachusetts.

https://doi.org/10.1124/jpet.116.239590.

S This article has supplemental material available at jpet.aspetjournals.org. numbers needed to treat, corresponding to the number of individuals receiving a treatment for one individual to achieve $50 \%$ or greater pain relief, range between 4 and 10 for current therapies (Nightingale, 2012; Finnerup et al., 2015). Between 2009 and 2014, 33 potential drugs for neuropathic pain, a form of chronic pain arising from damage to the somatosensory system that is particularly recalcitrant to treatment, were discontinued in clinical trials, highlighting the urgent need to both identify new targets as well as develop new therapeutic agents for treatment of pain indications (Knezevic et al., 2015).

$\mathrm{Na}_{\mathrm{V}} 1.7$ is a tetrodotoxin (TTX)-sensitive voltage-gated sodium ion channel that regulates action potential firing in nociceptor neurons within the peripheral nervous system (Klugbauer et al., 1995; Cummins et al., 1998; Black et al., 2012; Dib-Hajj et al., 2013). Sodium influx through $\mathrm{Na}_{v} 1.7$ generates ramp currents that can boost subthreshold

ABBREVIATIONS: ANOVA, analysis of variance; $\mathrm{CHO}$, Chinese hamster ovary; DMSO, dimethylsulfoxide; DRG, dorsal root ganglion; ESI, electrospray ionization; FBS, fetal bovine serum; $\mathrm{f}_{\mathrm{u}}$, unbound fraction; HEK, human embryonic kidney; $K_{\mathrm{i}}$, inhibition constant; $\mathrm{KO}$, knockout; TFA, trifluoroacetic acid; THF, tetrahydrofuran; TRPV1, transient receptor potential cation channel subfamily $\mathrm{V}$ member 1 ; TTX, tetrodotoxin; TTX-R, tetrodotoxin-resistant; TTX-S, tetrodotoxin-sensitive. 
depolarizing stimuli toward the threshold required to trigger sensory neuron action potentials, and $\mathrm{Na}_{\mathrm{V}} 1.7$ also contributes to the upstroke of nociceptor action potentials (Cummins et al., 1998; Rush et al., 2007; Alexandrou et al., 2016). In addition to its expression profile and role in action potential initiation, $\mathrm{Na}_{\mathrm{V}} 1.7$ represents a particularly compelling target for the development of chronic pain therapies due to its robust human genetic validation. Loss-of-function mutations lead to congenital insensitivity to pain (Cox et al., 2006; Goldberg et al., 2007), whereas gain-of-function mutations lead to pain in primary erythromelalgia, paroxysmal extreme pain disorder, and small-fiber neuropathy (Yang et al., 2004; Fertleman et al., 2006; Faber et al., 2012). Furthermore, in mice, genetic knockout of $\mathrm{Na}_{\mathrm{V}} 1.7$ in specific neuronal populations mitigates pain behavior after both inflammatory and nerve injury insults (Nassar et al., 2004; Minett et al., 2012), whereas global knockout of $\mathrm{Na}_{\mathrm{V}} 1.7$ from birth recapitulates the human phenotype of congenital insensitivity to pain (Gingras et al., 2014).

$\mathrm{Na}_{\mathrm{V}}$ 1.7 has been the intense focus of research activities to identify inhibitors for therapeutic development for chronic pain (Bagal et al., 2014; Sun et al., 2014a; de Lera Ruiz and Kraus, 2015; Emery et al., 2016; Vetter et al., 2017). Among these endeavors, sulfonamide-based small molecule antagonists have emerged as potent and selective compounds that block $\mathrm{Na}_{\mathrm{V}} 1.7$ with greatly reduced potency against homologous sodium channels, including $\mathrm{Na}_{\mathrm{V}} 1.5$, expressed in the heart. Mechanistically, block is achieved by engaging a novel binding pocket located within the fourth voltage-sensor domain and stabilizing $\mathrm{Na}_{\mathrm{V}} 1.7$ in an inactivated conformation, thereby preventing channels from efficiently recycling to the resting/closed state and reducing availability for subsequent opening events (McCormack et al., 2013; Sun et al., 2014b; Ahuja et al., 2015; Alexandrou et al., 2016; Focken et al., 2016; Theile et al., 2016). Poor inhibition of rat $\mathrm{Na}_{\mathrm{V}} 1.7$ channels by this chemotype is attributed to amino acid sequence differences in this region (McCormack et al., 2013; Alexandrou et al., 2016; Focken et al., 2016). Specific interaction with the fourth voltage-sensor domain differentiates the sulfonamide binding site from previously described $\mathrm{Na}_{\mathrm{V}}$ binding sites for toxin-derived peptides, local anesthetics, and TTX (de Lera Ruiz and Kraus, 2015).

Here, we describe an extensive in vitro, ex vivo, and in vivo preclinical pharmacological characterization of the novel sulfonamide $\mathrm{Na}_{\mathrm{V}} 1.7$ antagonist AMG8379 and its significantly less active enantiomer AMG8380, which serves as a negative control. AMG8379 represents a potent and selective $\mathrm{Na}_{\mathrm{V}} 1.7$ inhibitor that blocks action potential firing in peripheral nerve fibers and displays efficacy in translatable mouse models of both itch and pain, whereas the less active enantiomer AMG8380 is devoid of these biologic effects at comparable plasma concentrations.

\section{Materials and Methods}

\section{Cell Lines}

Human Nav1.1 human embryonic kidney (HEK) 293, Nav1.2 and $\mathrm{Na}_{\mathrm{V}} 1.3$ Chinese hamster ovary (CHO), Na 1.4 HEK293, Na 1.5 HEK293, $\mathrm{Na}_{\mathrm{V}} 1.6 \mathrm{HEK} 293$, and $\mathrm{Na}_{\mathrm{V}} 1.7$ HEK293 stable cell lines were purchased from Eurofins Pharma Discovery Services (St. Charles, MO). $\mathrm{Na}_{\mathrm{V}} 1.1, \mathrm{Na}_{\mathrm{V}} 1.4, \mathrm{Na}_{\mathrm{V}} 1.5$, and $\mathrm{Na}_{\mathrm{V}} 1.7$ cell lines were maintained in Dulbecco's modified Eagle's medium/F12 medium supplemented with certified fetal bovine serum (FBS) $10 \% \mathrm{v} / \mathrm{v}, 1 \%$ minimal essential medium nonessential amino acids, 100 units $/ \mathrm{ml}$ penicillin, $100 \mu \mathrm{g} / \mathrm{ml}$ streptomycin, and $0.292 \mathrm{mg} / \mathrm{ml}$ L-glutamine (Gibco Life Technologies, Indianapolis, IN). Nav1.2 and $\mathrm{Na}_{V} 1.3$ cell lines were maintained in Iscove's modified Dulbecco's medium supplemented with dialyzed FBS $10 \% \mathrm{v} / \mathrm{v}, 1 \%$ sodium hypoxanthine and thymidine (HT) supplement, $1 \%$ minimal essential medium nonessential amino acids, $100 \mathrm{units} / \mathrm{ml}$ penicillin, $100 \mu \mathrm{g} / \mathrm{ml}$ streptomycin, and $0.292 \mathrm{mg} / \mathrm{ml}$ L-glutamine (Gibco Life Technologies). All cell lines were maintained at $37^{\circ} \mathrm{C}$ in a humidified $95 \% \mathrm{O}_{2} / 5 \% \mathrm{CO}_{2}$ atmosphere in the presence of the selection antibiotic geneticin $400 \mu \mathrm{g} / \mathrm{ml}$ (Gibco Life Technologies). U-2 OS cells were maintained and transduced at 200 multiplicity of infection with mouse $\mathrm{Na}_{\mathrm{V}} 1.1$ or mouse $\mathrm{Na}_{\mathrm{v}}$ 1.6 BacMam viruses as previously described (Liu et al., 2016). For routine passaging, cells were lifted with $0.05 \%$ trypsin-EDTA (Gibco Life Technologies) and grown in T-75 or T-150 flasks (Corning, Corning, $\mathrm{NY})$ to $50-80 \%$ confluency to prevent contact inhibition of channel expression. Mouse and rat $\mathrm{Na}_{\mathrm{V}} 1.7$ sequences were subcloned into the antibiotic selection vector pSLX240h, linearized, and stably transfected using Lipofectamine LTX into HEK293 (for mouse Nav1.7) or HEK293T (for rat $\mathrm{Na}_{\mathrm{V}} 1.7$ ). After 48-72 hours of transfection, media containing $80 \mu \mathrm{g} / \mathrm{ml}$ hygromycin was added, and selection was continued for 24-30 days. Individual colonies were picked into 96-well plates and expanded, and expression was confirmed by electrophysiology testing.

\section{Experimental Procedures for the Preparation of AMG8379 and AMG8380}

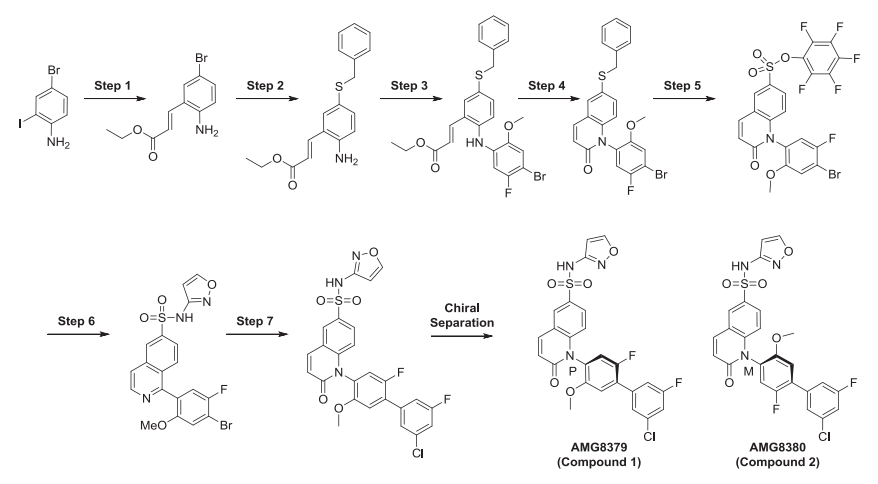

Step 1: (E)-Ethyl 3-(2-Amino-5-Bromophenyl)acrylate. To a solution of 4-bromo-2-iodoaniline $(25.0 \mathrm{~g}, 84 \mathrm{mmol})$ in dimethyl formamide $(56.0 \mathrm{ml})$ was added ethyl acrylate $(8.8 \mathrm{~g}, 88 \mathrm{mmol})$ and sodium bicarbonate (17.62 $\mathrm{g}, 210 \mathrm{mmol})$. The reaction mixture was degassed with nitrogen for 20 minutes followed by the addition of palladium acetate $(0.94 \mathrm{~g}, 4.20 \mathrm{mmol})$. The reaction mixture was heated at $100^{\circ} \mathrm{C}$ for 4 hours. The reaction was filtered through celite, and the celite bed was washed with ethyl acetate $(2 \times 500 \mathrm{ml})$. The filtrate was concentrated under reduced pressure to obtain a crude residue, which was purified by column chromatography (silica gel; mesh size 60-120, elution 0-20\% ethyl acetate in hexanes), to obtain (E)-ethyl 3-(2-amino-5-bromophenyl)acrylate $(20.4 \mathrm{~g}, 90 \%)$ as a yellow solid [MS (electrospray ionization [ESI], positive ion) $\mathrm{m} / \mathrm{z}$ : $271.2(\mathrm{M}+1) ;{ }^{1} \mathrm{H}$ NMR (400 MHz, dimethylsulfoxide [DMSO]); $\delta 7.75$ $\left(\mathrm{d}, J=16.1 \mathrm{~Hz},{ }^{1} \mathrm{H}\right) ; 7.57\left(\mathrm{~d}, J=2.0 \mathrm{~Hz},{ }^{1} \mathrm{H}\right) ; 7.16(\mathrm{dd}, J=9.1,2.4 \mathrm{~Hz}$, $\left.{ }^{1} \mathrm{H}\right) ; 6.66\left(\mathrm{~d}, J=8.6 \mathrm{~Hz},{ }^{1} \mathrm{H}\right) ; 6.43\left(\mathrm{~d}, J=8.6 \mathrm{~Hz},{ }^{1} \mathrm{H}\right) ; 5.81\left(\mathrm{~s},{ }^{2} \mathrm{H}\right) ; 4.20$ $\left(\mathrm{q}, J=7.2 \mathrm{~Hz},{ }^{2} \mathrm{H}\right)$; and $\left.1.27\left(\mathrm{t}, J=7.2 \mathrm{~Hz},{ }^{3} \mathrm{H}\right)\right]$.

Step 2: (E)-Ethyl 3-(2-Amino-5-(Benzylthio)phenyl)acrylate. To a solution of (E)-ethyl 3-(2-amino-5-bromophenyl)acrylate $(20.0 \mathrm{~g}$, $74 \mathrm{mmol}$ ) in 1,4-dioxane (74 ml) was added diisopropylethylamine (25.8 $\mathrm{ml}, 148 \mathrm{mmol})$. The solution was degassed with nitrogen for 
20 minutes, at which point XantaPhos $(2.14 \mathrm{~g}, 3.70 \mathrm{mmol})$ and $\mathrm{Pd}_{2}(\mathrm{dba})_{3}(1.67 \mathrm{~g}, 1.85 \mathrm{mmol})$ were added to the reaction mixture. The mixture was purged with nitrogen and heated to $80^{\circ} \mathrm{C}$ for 30 minutes. The reaction was cooled to room temperature, benzyl mercaptan $(9.66 \mathrm{~g}, 78 \mathrm{mmol})$ was added, and the reaction was heated at $80^{\circ} \mathrm{C}$ for an additional 2 hours. The reaction was cooled to room temperature and diluted with ethyl acetate. The mixture was filtered through celite, and the celite bed was washed with ethyl acetate. The filtrate was concentrated under reduced pressure to obtain the crude material, which was purified by chromatography (silica gel; mesh size 60-120, elution 0-40\% ethyl acetate and heptane) to obtain (E)-ethyl 3-(2-amino-5-(benzylthio)phenyl)acrylate $(21.4 \mathrm{~g}, 92 \%)$, as a yellow solid [MS (ESI, positive ion) m/z: $314.1(\mathrm{M}+1){ }^{1} \mathrm{H}$ NMR $(400 \mathrm{MHz}$, DMSO); $\delta 7.79\left(\mathrm{~d}, J=16.1 \mathrm{~Hz},{ }^{1} \mathrm{H}\right) ; 7.37\left(\mathrm{~d}, J=2.0 \mathrm{~Hz},{ }^{1} \mathrm{H}\right) ; 7.25-7.17$ $\left(\mathrm{m},{ }^{5} \mathrm{H}\right) ; 7.10\left(\mathrm{dd}, J=8.4,2.1 \mathrm{~Hz},{ }^{1} \mathrm{H}\right) ; 6.61\left(\mathrm{~d}, J=8.3 \mathrm{~Hz},{ }^{1} \mathrm{H}\right) ; 6.32(\mathrm{~d}, J=$ $\left.15.2 \mathrm{~Hz},{ }^{1} \mathrm{H}\right) ; 5.75\left(\mathrm{~s},{ }^{2} \mathrm{H}\right) ; 4.20\left(\mathrm{q}, J=7.2 \mathrm{~Hz},{ }^{2} \mathrm{H}\right) ; 4.01\left(\mathrm{~s},{ }^{2} \mathrm{H}\right)$; and 1.27 (t, $\left.\left.J=7.2 \mathrm{~Hz},{ }^{3} \mathrm{H}\right)\right]$.

Step 3: (E)-Ethyl 3-(5-(Benzylthio)-2-((4-Bromo-5-Fluoro-2Methoxyphenyl)amino)phenyl)acrylate. To a solution of (E)ethyl 3-(2-amino-5-(benzylthio)phenyl)acrylate $(5.00 \mathrm{~g}, 15.9 \mathrm{mmol})$ and 1-bromo-2-fluoro-4-iodo-5-methoxybenzene (6.34 g, $19.1 \mathrm{mmol})$ in cyclopentyl methyl ether $(32 \mathrm{~mL})$ was added $\mathrm{Cs}_{2} \mathrm{CO}_{3}(7.28 \mathrm{~g}$, $22.3 \mathrm{mmol}$ ), and the mixture was degassed with nitrogen for $20 \mathrm{~min}$ utes. $\mathrm{Pd}_{2}(\mathrm{dba})_{3}(0.37 \mathrm{~g}, 0.40 \mathrm{mmol})$ and XantaPhos $(0.46 \mathrm{~g}, 0.80 \mathrm{mmol})$ were added to the reaction mixture, and the mixture was heated at $90^{\circ} \mathrm{C}$ for 3 hours. The reaction mixture was allowed to cool to room temperature, diluted with ethyl acetate, and filtered through celite. The filtrate was concentrated under reduced pressure to obtain the crude material, which was purified by stirring with isopropanol for 16 hours and filtered to obtain (E)-ethyl 3-(5-(benzylthio)-2-((4bromo-5-fluoro-2-methoxyphenyl)amino)phenyl)acrylate (7.27 g, 88\%) as a yellow solid [MS (ESI, positive ion) $\mathrm{m} / \mathrm{z}$ : $516.2(\mathrm{M}+1)^{1} \mathrm{H}$ NMR (400 MHz, DMSO); $\delta 7.73-7.61\left(\mathrm{~m},{ }^{3} \mathrm{H}\right) ; 7.34-7.15\left(\mathrm{~m},{ }^{6} \mathrm{H}\right)$; $7.02\left(\mathrm{~d}, J=11.4 \mathrm{~Hz},{ }^{1} \mathrm{H}\right) ; 6.60\left(\mathrm{~d}, J=21.2 \mathrm{~Hz},{ }^{1} \mathrm{H}\right) ; 6.33(\mathrm{~d}, J=14.1 \mathrm{~Hz}$, $\left.{ }^{1} \mathrm{H}\right) ; 4.26\left(\mathrm{~s},{ }^{2} \mathrm{H}\right) ; 4.16-4.09\left(\mathrm{~m},{ }^{2} \mathrm{H}\right) ; 3.81\left(\mathrm{~s},{ }^{3} \mathrm{H}\right)$, and $\left.1.22\left(\mathrm{t}, J=7.2 \mathrm{~Hz},{ }^{3} \mathrm{H}\right)\right]$.

Step 4: 6-(Benzylthio)-1-(4-Bromo-5-Fluoro-2-Methoxyphenyl)quinolin-2(1H)-One. A round-bottom flask was charged with (E)-ethyl 3-(5(benzylthio)-2-((4-bromo-5-fluoro-2-methoxyphenyl)amino)phenyl)acrylate $(7.27 \mathrm{~g}, 14.08 \mathrm{mmol})$ and $\mathrm{MeOH}(70.4 \mathrm{ml})$ to give a yellow suspension. Sodium methoxide (25 wt\% in $\mathrm{MeOH})(1.25 \mathrm{ml}, 5.63 \mathrm{mmol})$ was added. A reflux condenser was attached, and the flask was lowered into a $70^{\circ} \mathrm{C}$ heating bath. After 4 hours, the mixture was cooled and concentrated under vacuum to obtain the crude material, which was purified by stirring with isopropanol for 16 hours and filtered to give 6-(benzylthio)-1-(4-bromo-5-fluoro-2-methoxyphenyl)quinolin-2(1H)-one (6.05 g, 91\% yield) [MS (ESI, positive ion) $\mathrm{m} / \mathrm{z}: 470.0(\mathrm{M}+1)^{1} \mathrm{H} \mathrm{NMR}$ (400 MHz, DMSO); $\delta 7.92\left(\mathrm{~d}, J=9.1 \mathrm{~Hz},{ }^{1} \mathrm{H}\right) ; 7.79\left(\mathrm{~d}, J=1.7 \mathrm{~Hz},{ }^{1} \mathrm{H}\right)$; $7.65\left(\mathrm{~d}, J=6.1 \mathrm{~Hz},{ }^{1} \mathrm{H}\right) ; 7.57\left(\mathrm{~d}, J=8.8 \mathrm{~Hz},{ }^{1} \mathrm{H}\right) ; 7.40-7.22\left(\mathrm{~m},{ }^{6} \mathrm{H}\right) ; 6.68$ $\left(\mathrm{d}, J=9.6 \mathrm{~Hz},{ }^{1} \mathrm{H}\right) ; 6.56\left(\mathrm{~d}, J=8.8 \mathrm{~Hz},{ }^{1} \mathrm{H}\right) ; 4.24\left(\mathrm{~s},{ }^{2} \mathrm{H}\right)$; and $\left.3.69\left(\mathrm{~s},{ }^{3} \mathrm{H}\right)\right]$.

Step 5: Perfluorophenyl 1-(4-Bromo-5-Fluoro-2-Methoxyphenyl)2-Oxo-1,2-Dihydroquinoline-6-Sulfonate. To a solution of 6-(benzylthio)1-(4-bromo-5-fluoro-2-methoxyphenyl)quinolin-2 $\left({ }^{1} \mathrm{H}\right)-1(6.00 \mathrm{~g}, 12.76 \mathrm{mmol})$ in acetonitrile $(40.0 \mathrm{ml})$ were added acetic acid $(1.5 \mathrm{ml})$ and water $(1.0 \mathrm{ml})$. The resulting mixture was cooled to $0^{\circ} \mathrm{C}$, and 1,3-dichloro5,5-dimethylimidazolidine-2,4-dione ( $2.64 \mathrm{~g}, 13.4 \mathrm{mmol})$ was added portionwise over 20 minutes while keeping the internal temperature below $5^{\circ} \mathrm{C}$. The resulting suspension was stirred at $0-5^{\circ} \mathrm{C}$ under nitrogen for 45 minutes. Then pentafluorophenol $(2.82 \mathrm{~g}$, $15.31 \mathrm{mmol})$ was added followed by $\mathrm{NEt}_{3}(7.11 \mathrm{ml}, 51.0 \mathrm{~mol})$. The mixture continued to be stirred at $0-5^{\circ} \mathrm{C}$ for 30 minutes. Water was added and extracted with ethyl acetate. The organic layer was washed with brine, dried over sodium sulfate, filtered, and concentrated under reduced pressure to obtain the crude product, which was purified by stirring with isopropyl alcohol/hexanes (1:1) and filtered to obtain perfluorophenyl 1-(4-bromo-5-fluoro-2methoxyphenyl)-2-oxo-1,2-dihydroquinoline-6-sulfonate $(6.05 \mathrm{~g}$, $80 \%$ ) as a white solid [MS (ESI, positive ion) $\mathrm{m} / \mathrm{z}: 594.2(\mathrm{M}+1)$ ${ }^{1} \mathrm{H}-\mathrm{NMR}(400 \mathrm{MHz}, \mathrm{DMSO}) ; \delta 8.60\left(\mathrm{~d}, J=2.0 \mathrm{~Hz},{ }^{1} \mathrm{H}\right) ; 8.26(\mathrm{~d}, J=9.8 \mathrm{~Hz}$, $\left.{ }^{1} \mathrm{H}\right) ; 7.95\left(\mathrm{dd}, J=2.2,9.1 \mathrm{~Hz},{ }^{1} \mathrm{H}\right) ; 7.70\left(\mathrm{t}, J=8.6 \mathrm{~Hz},{ }^{2} \mathrm{H}\right) ; 6.95-6.88\left(\mathrm{~m},{ }^{2} \mathrm{H}\right)$; and $\left.3.72\left(\mathrm{~s},{ }^{3} \mathrm{H}\right)\right]$.

Step 6: 1-(4-Bromo-5-Fluoro-2-Methoxyphenyl)- $N$-(Isoxazol3-yl)-2-Oxo-1,2-Dihydroquinoline-6-Sulfonamide. A tetrahydrofuran (THF; $50 \mathrm{ml}$ ) solution of perfluorophenyl 1-(4-bromo-5-fluoro-2methoxyphenyl)-2-oxo-1,2-dihydroquinoline-6-sulfonate (3.00 g, $5.05 \mathrm{mmol})$ and 3 -aminoisoxazole $(0.41 \mathrm{ml}, 5.55 \mathrm{mmol})$ in a 250 - $\mathrm{ml}$ round-bottom flask was cooled to $0^{\circ} \mathrm{C}$, and lithium bis(trimethylsilyl)amide, $1.0 \mathrm{M}$ solution in THF (10.6 ml, $10.6 \mathrm{mmol}$ ) was added dropwise. After stirring the solution at $0^{\circ} \mathrm{C}$ for 1 hour, the reaction was quenched at $0^{\circ} \mathrm{C}$ with $1 \mathrm{~N} \mathrm{HCl}$ and extracted three times with EtOAc. The organic extracts were combined, dried over MgSO4, filtered, and concentrated to a light tan residue, yielding $3.81 \mathrm{~g}$ of the product. The resulting filtrate was concentrated under reduced pressure to obtain the crude product, which was purified by stirring with ethyl acetate and filtered to obtain 1-(4-bromo-5-fluoro-2-methoxyphenyl)- $N$-(isoxazol3-yl)-2-oxo-1,2-dihydroquinoline-6-sulfonamide ( $2.08 \mathrm{~g}, 83 \%$ yield $)$ was afforded as an off-white solid [m/z (ESI): $494.1(\mathrm{M}+\mathrm{H}){ }^{+1} \mathrm{H}$ NMR $\left(400 \mathrm{MHz}, \mathrm{DMSO}-\mathrm{d}_{6}\right) ; \delta=11.66$ (broad singlet, $\left.{ }^{1} \mathrm{H}\right) ; 8.72(\mathrm{~d}, J=$ $\left.1.8 \mathrm{~Hz},{ }^{1} \mathrm{H}\right) ; 8.35\left(\mathrm{~d}, J=2.2 \mathrm{~Hz},{ }^{1} \mathrm{H}\right) ; 8.21\left(\mathrm{~d}, J=9.6 \mathrm{~Hz},{ }^{1} \mathrm{H}\right) ; 7.83(\mathrm{dd}$, $\left.J=2.2,8.9 \mathrm{~Hz},{ }^{1} \mathrm{H}\right) ; 7.52\left(\mathrm{~s},{ }^{1} \mathrm{H}\right) ; 7.34\left(\mathrm{~d}, J=0.4 \mathrm{~Hz},{ }^{1} \mathrm{H}\right) ; 6.78(\mathrm{~d}, J=$ $\left.9.6 \mathrm{~Hz},{ }^{2} \mathrm{H}\right) ; 6.43\left(\mathrm{~d}, J=1.9 \mathrm{~Hz},{ }^{1} \mathrm{H}\right)$; and $\left.3.67\left(\mathrm{~s},{ }^{3} \mathrm{H}\right)\right]$.

Step 7: (P)-1-(3'-Chloro-2,5' -Difluoro-5-Methoxy-4-Biphenylyl)$\mathrm{N}$-3-Isoxazolyl-2-Oxo-1,2-Dihydro-6-Quinolinesulfonamide (Compound 1; AMG8379) and (M)-1-(3'-Chloro-2,5'-Difluoro5-Methoxy-4-Biphenylyl)- $\mathrm{N}$-3-Isoxazolyl-2-Oxo-1,2-Dihydro6-Quinolinesulfonamide (Compound 2: AMG8380). A screw-cap vial was charged with 1-(4-bromo-5-fluoro-2-methoxyphenyl)- $N$-(isoxazol-3yl)-2-oxo-1,2-dihydroquinoline-6-sulfonamide $(2.00 \mathrm{~g}, 4.05 \mathrm{mmol})$, (3-chloro-5-fluorophenyl)boronic acid (1.058 g, $6.07 \mathrm{mmol})$, potassium carbonate $(1.678 \mathrm{~g}, 12.14 \mathrm{mmol})$, and $\mathrm{Pd}\left(\mathrm{Ph}_{3} \mathrm{P}\right)_{4}(0.468 \mathrm{~g}, 0.405 \mathrm{mmol})$. The vial was flushed with $\mathrm{Ar}(\mathrm{g})$, and then 1,4-dioxane (15 ml) and water $(5 \mathrm{ml})$ were added in sequence. The reaction was heated to $90^{\circ} \mathrm{C}$ for 3 hours. The mixture was diluted with $\mathrm{NH}_{4} \mathrm{Cl}$ and extracted with EtOAc $(3 \times)$.The combined organic extracts were dried over magnesium sulfate, filtered, and concentrated. The residue was purified by chromatography on silica gel (40-g Ultra SNAP column, 25-g silica gel loading column, 0-50\% EtOAc/ heptane) to give 1-(3'-chloro-2,5'-difluoro-5-methoxy-4-biphenylyl)- $N$ 3-isoxazolyl-2-oxo-1,2-dihydro-6-quinolinesulfonamide (1.85 g, 84\% yield) as a cream-colored solid [m/z (ESI) $\left.544.2(\mathrm{M}+\mathrm{H})^{+}\right]$.

\section{Chiral Separation}

Racemic 1-(3'-chloro-2,5'-difluoro-5-methoxy-4-biphenylyl)- $N$-3isoxazolyl-2-oxo-1,2-dihydro-6-quinolinesulfonamide was subjected to chiral separation by supercritical fluid chromatography (SFC) using an AS-H column (25\% $\left.\mathrm{MeOH} / 75 \% \mathrm{CO}_{2}\right)$ to give (P)-1-(3'-chloro-2,5'difluoro-5-methoxy-4-biphenylyl)-N-3-isoxazolyl-2-oxo-1,2-dihydro6-quinolinesulfonamide (compound 1; AMG8379) as peak 1 and (M)-1-(3'-chloro-2,5' -difluoro-5-methoxy-4-biphenylyl)- $N$-3-isoxazolyl-2oxo-1,2-dihydro-6-quinolinesulfonamide as peak 2 (compound 2; AMG8380). Data for peak 1 are as follows: ${ }^{1} \mathrm{H}$ NMR (500 MHz, DMSO-d 6 ) $\delta$ 11.56-11.84 (broad singlet, $1 \mathrm{H}) ; 11.56-11.84\left(\mathrm{~m},{ }^{1} \mathrm{H}\right) ; 8.71(\mathrm{~d}, J=$ $\left.1.60 \mathrm{~Hz},{ }^{1} \mathrm{H}\right) ; 8.37\left(\mathrm{~d}, J=1.87 \mathrm{~Hz},{ }^{1} \mathrm{H}\right) ; 8.23\left(\mathrm{~d}, J=9.67 \mathrm{~Hz},{ }^{1} \mathrm{H}\right) ; 7.86(\mathrm{dd}$, $\left.J=2.00,8.95 \mathrm{~Hz},{ }^{1} \mathrm{H}\right) ; 7.66\left(\mathrm{~s},{ }^{1} \mathrm{H}\right) ; 7.53-7.63\left(\mathrm{~m},{ }^{3} \mathrm{H}\right) ; 7.47(\mathrm{~d}, J=6.84 \mathrm{~Hz}$, $\left.{ }^{1} \mathrm{H}\right) ; 6.86\left(\mathrm{~d}, J=8.98 \mathrm{~Hz},{ }^{1} \mathrm{H}\right) ; 6.81\left(\mathrm{~d}, J=9.67 \mathrm{~Hz},{ }^{1} \mathrm{H}\right)$; and $3.75\left(\mathrm{~s},{ }^{3} \mathrm{H}\right)$; $\mathrm{m} / \mathrm{z}$ (ESI) $542.1(\mathrm{M}-\mathrm{H})^{-}$. Data for peak 2 are as follows: ${ }^{1} \mathrm{H}$ NMR $\left(500 \mathrm{MHz}, \mathrm{DMSO}-\mathrm{d}_{6}\right) \delta 11.39-11.86\left(\mathrm{br} \mathrm{s},{ }^{1} \mathrm{H}\right) ; 8.71\left(\mathrm{~d}, J=1.55 \mathrm{~Hz},{ }^{1} \mathrm{H}\right)$; $8.37\left(\mathrm{~d}, J=1.87 \mathrm{~Hz},{ }^{1} \mathrm{H}\right) ; 8.23\left(\mathrm{~d}, J=9.72 \mathrm{~Hz},{ }^{1} \mathrm{H}\right) ; 7.85(\mathrm{dd}, J=2.06$, $\left.8.90 \mathrm{~Hz},{ }^{1} \mathrm{H}\right) ; 7.66\left(\mathrm{~s},{ }^{1} \mathrm{H}\right) ; 7.51-7.63\left(\mathrm{~m},{ }^{3} \mathrm{H}\right) ; 7.47\left(\mathrm{~d}, J=6.89 \mathrm{~Hz},{ }^{1} \mathrm{H}\right) ; 6.85$ $\left(\mathrm{d}, J=9.03 \mathrm{~Hz},{ }^{1} \mathrm{H}\right) ; 6.81\left(\mathrm{~d}, J=9.67 \mathrm{~Hz},{ }^{1} \mathrm{H}\right) ; 6.44\left(\mathrm{~d}, J=1.55 \mathrm{~Hz},{ }^{1} \mathrm{H}\right)$; and $3.75\left(\mathrm{~s},{ }^{4} \mathrm{H}\right) \mathrm{m} / \mathrm{z}$ (ESI) $542.1(\mathrm{M}-\mathrm{H})^{-}$

The $\mathrm{Na}_{\mathrm{V}} 1.8$ blocker compound 31 was from the study by Kort et al. (2010).

\section{Radioligand Binding Assay}

Binding of AMG8379 and AMG8380 to membranes from human Nav1.7 HEK293 cells was performed as previously described 
(DiMauro et al., 2016) using the tritiated sulfonamide radioligand 4 that is described below.

Preparation of Radiolabeled Sulfonamide ((P)-1-(3-Chloro-2Fluoro-5,5-Dimethoxy-[1,1-Biphenyl]-4-yl)- $N$-(Isoxazol-3-yl)-2-Oxo1,2-Dihydroquinoline-6-Sulfonamide [5-Methoxy-C ${ }^{3} \mathrm{H}_{3}$ ].

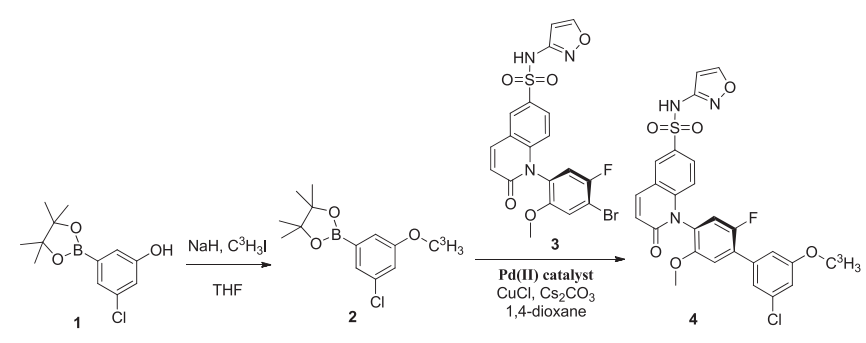

$\mathrm{NaH}$ (60\% dispersion in mineral oil, $15.8 \mathrm{mg}, 395 \mu \mathrm{mol}$ ) was weighed into a flask and washed twice with $n$-heptane $(1 \mathrm{ml})$. Dry THF $(1.00 \mathrm{ml})$ was added, followed by a solution of compound 1 (3-chloro-5-(4,4,5,5tetramethyl-1,3,2-dioxaborolan-2-yl)phenol) (33.5 mg, $132 \mu \mathrm{mol})$ in dry THF $(0.50 \mathrm{ml})$. The mixture was allowed to stir for 20 minutes at room temperature under a nitrogen atmosphere, at which time a solution of $\mathrm{C}^{3} \mathrm{H}_{3} \mathrm{I}(400 \mathrm{mCi}, 6.5 \mu \mathrm{mol})$ in dry THF $(0.5 \mathrm{ml})$ was added. The reaction mixture was stirred at room temperature for 36 hours before being diluted with dichloromethane $(1.0 \mathrm{ml})$ and filtered through celite. The clear organic solution was concentrated to provide compound 2 (2(3-chloro-5-methoxyphenyl)-4,4,5,5-tetramethyl-1,3,2-dioxaborolane [5methoxy- $\left.\mathrm{C}^{3} \mathrm{H}_{3}\right]$ ), which was subsequently dissolved in 1,4-dioxane $(0.2 \mathrm{ml})$. To this solution was added $\mathrm{Cs}_{2} \mathrm{CO}_{3}(11.8 \mathrm{mmol}, 36.2 \mu \mathrm{mol})$, $\mathrm{CuCl}$ (2.68 mg, $27.1 \mu \mathrm{mol})$, compound 3* ((P)-1-(4-bromo-5-fluoro-2methoxyphenyl)- $N$-(isoxazol-3-yl)-2-oxo-1,2-dihydroquinoline6 -sulfonamide) $(4.91 \mathrm{mg}, 9.93 \mu \mathrm{mol})$, and bis(di-tert-butyl(4dimethylaminophenyl)phosphine)dichloropalladium(II) (1.92 mg, $2.71 \mu \mathrm{mol})$. The mixture was stirred at $50^{\circ} \mathrm{C}$ for 5 hours. The reaction was cooled to room temperature, filtered through celite and washed with $\mathrm{MeOH}(10 \mathrm{ml})$. The filtrate was concentrated under reduced pressure, and the residue was purified by preparative high-performance liquid chromatography [Waters (Milford, MA) X-Bridge C18 Column; $10.0 \times 150 \mathrm{~mm}, 5 \mu \mathrm{m}$; mobile phase A $0.1 \%$ trifluoroacetic acid (TFA) water; mobile phase B $0.1 \%$ TFA acetonitrile; gradient: (minimum, $\mathrm{B} \%)=(0,40) \rightarrow(20,100) \rightarrow(25,100) \rightarrow(25.1,40) \rightarrow(30,40) ; 5.0 \mathrm{ml} / \mathrm{min}$, $254 \mathrm{~nm}$ ] to afford a solution of compound 4 . To the derived solution was added saturated aqueous $\mathrm{NaHCO}_{3}(0.1 \mathrm{ml})$, and the mixture was loaded onto a BAKERBOND SPE C18 cartridge $(6 \mathrm{ml}, 500 \mathrm{mg}$; catalog \#7020-06; J.T.Baker, Phillipsburg, New Jersey). The cartridge was rinsed with water, and then the desired product was eluted with ethanol to provide crude compound 4 . This material was subsequently repurified via chiral preparative high-performance liquid chromatography $(4.6 \times 250 \mathrm{~mm}$, $5 \mu \mathrm{m}$; mobile phase: TFA $/ n$-heptane $/ \mathrm{EtOH}=0.2 / 75 / 25 ; 1.0 \mathrm{ml} / \mathrm{min}$; $254 \mathrm{~nm}$; CHIRALCEL OD-H; Chiral Technologies Europe SAS, Illkirch, France). The combined fractions containing compound 4 were treated with saturated aqueous $\mathrm{NaHCO}_{3}(0.1 \mathrm{ml})$. This mixture was loaded onto a BAKERBOND SPE C18 Cartridge (6 ml, 500 mg; catalog \#7020-06). The cartridge was rinsed with water, and then the desired product was eluted with ethanol to provide ((P)-1-(3-chloro-2-fluoro-5,5-dimethoxy[1,1-biphenyl]-4-yl)-N-(isoxazol-3-yl)-2-oxo-1,2-dihydroquinoline-6sulfonamide [5-methoxy- $\left.\left.\mathrm{C}^{3} \mathrm{H}_{3}\right]\right)$ as a white solid [185 $\mathrm{MBq}(5.0 \mathrm{mCi})$, $37 \mathrm{MBq}(1.0 \mathrm{mCi})$ in $\mathrm{EtOH}$. Radioligand 4 corresponds to tritiated compound 501, and intermediate 3 corresponds to :Intermediate BN: from the study by Weiss et al. (2014)

\section{PatchXpress 7000A Electrophysiology}

Sodium currents were recorded in whole-cell voltage clamp mode with the PatchXpress automated electrophysiology system (Molecular Devices, LLC, Sunnyvale, CA). Adherent cells were isolated from tissue culture flasks using trypsin-EDTA treatment for 2-3 minutes and then incubated in complete culture medium containing $10 \%$ FBS for at least 15 minutes prior to resuspension in external solution consisting of $70 \mathrm{mM} \mathrm{NaCl}, 140 \mathrm{mM}$ D-Mannitol, $5 \mathrm{mM} \mathrm{KCl,} 11 \mathrm{mM}$ glucose, $10 \mathrm{mM}$ HEPES, $2 \mathrm{mM} \mathrm{CaCl}_{2}$, and $1 \mathrm{mM} \mathrm{MgCl}_{2}, \mathrm{pH} 7.4$, with $\mathrm{NaOH}$. The internal solution consisted of $62.5 \mathrm{mM} \mathrm{CsCl}, 75 \mathrm{mM} \mathrm{CsF}$, 10 HEPES, $5 \mathrm{mM}$ EGTA, and $2.5 \mathrm{mM} \mathrm{MgCl}_{2}$, pH 7.25, with $\mathrm{CsOH}$. Cells were voltage clamped at room temperature at a holding potential of $-125 \mathrm{mV}$ with test potentials to $-10 \mathrm{mV}\left(\mathrm{Na}_{\mathrm{v}} 1.7\right)$ or $-20 \mathrm{mV}$ $\left(\mathrm{Na}_{\mathrm{V}} 1.5\right)$. Compound effects were measured on a partially inactivated state of sodium channels. For human, mouse, and rat $\mathrm{Na}_{\mathrm{V}} 1.7$, cells were clamped to a holding potential yielding $20-50 \%$ inactivation. To elicit sodium current, channels were activated by pulsing to $-10 \mathrm{mV}$ for 15 milliseconds. This voltage protocol was repeated at a rate of $0.1 \mathrm{~Hz}$ throughout the experiment. To evaluate AMG8379 inhibition of human $\mathrm{Na}_{\mathrm{V}} 1.7$ in the closed/resting state, cells were clamped to a holding potential of $-125 \mathrm{mV}$ and activated by pulsing to $-10 \mathrm{mV}$ for 15 milliseconds. For human $\mathrm{Na}_{\mathrm{V}} 1.5$, cells were held at a holding potential of $-50 \mathrm{mV}$. To elicit sodium currents, the voltage was changed to $-120 \mathrm{mV}$ for a period of 50 milliseconds before a test pulse to $-20 \mathrm{mV}$ of 20 milliseconds duration. These voltage protocols were repeated at a rate of $0.1 \mathrm{~Hz}$ throughout the experiment. A single concentration of test compound was applied to cells for 3-5 minutes. The peak sodium current was measured at the end of the compound addition period to determine the percentage of inhibition. Cells were used for additional compound testing if currents recovered to $>80 \%$ of starting values after compound washout. $\mathrm{IC}_{50}$ values were calculated by pooling single-point determinations from three to five cells at different compound concentrations and fitting the resulting dataset with a Hill (fourparameter logistic) fit in DataXpress version 2.0 software.

\section{IonWorks Quattro Electrophysiology}

Sodium currents were recorded in population patch clamp mode with the IonWorks Quattro automated electrophysiology system using the PatchPlate PPC population recording substrate (Molecular Devices, LLC). This system utilizes perforated patch clamp technology to gain electrical access to cells. For assay, cells were grown to 60-90\% confluency and lifted for 3 minutes at $37^{\circ} \mathrm{C}$ with either $0.25 \%$ trypsinEDTA (Gibco Life Technologies) for $\mathrm{Na}_{V} 1.1, \mathrm{Na}_{\mathrm{V}} 1.4, \mathrm{Na}_{\mathrm{V}} 1.5, \mathrm{Na}_{\mathrm{V}} 1.6$, and $\mathrm{Na}_{\mathrm{V}} 1.7$ or TrypLE Express (Gibco Life Technologies) for Nav1.2 and $\mathrm{Na}_{\mathrm{V}}$ 1.3. Growth media were then added to the flasks, and the cells were lightly triturated and then spun down for 3 minutes at $230 g$. Cells were resuspended in external physiologic saline (see below) at 2.5 million cells/ml for assay.

External saline consisted of the following (in $\mathrm{mM}$ ): $\mathrm{NaCl} 140, \mathrm{KCl} 5$, $\mathrm{CaCl}_{2} 2 \mathrm{MgCl}_{2}$ 1, HEPES 10, and glucose 11, pH 7.4, with $N$-methyl-Dglucamine at $320 \mathrm{mOsmol}$. The internal solution for $\mathrm{Na}_{\mathrm{V}} 1.1, \mathrm{Na}_{\mathrm{V}} 1.4$, $\mathrm{Na}_{\mathrm{V}} 1.5, \mathrm{Na}_{\mathrm{v}} 1.6$, and $\mathrm{Na}_{\mathrm{v}} 1.7$ consisted of the following (in $\mathrm{mM}$ ): $\mathrm{KCl}$ $70, \mathrm{KF} 70, \mathrm{MgCl}_{2}$ 0.25, HEDTA 5, and HEPES 10, pH 7.25, with $N$ methyl-D-glucamine, $300 \mathrm{mOsmol}$. We found that $\mathrm{Na}_{\mathrm{V}} 1.2$ and $\mathrm{Na}_{\mathrm{v}} 1.3$ currents were unstable with fluoride-based internal solution and switched to a potassium gluconate-based solution, which improved results. The internal solution used for $\mathrm{Na}_{\mathrm{V}} 1.2$ and $\mathrm{Na}_{\mathrm{v}} 1.3$ consisted of the following (in $\mathrm{mM}$ ): $\mathrm{K}$ gluconate $100, \mathrm{KCl} 30, \mathrm{MgCl}_{2} 3.2$, EGTA 5, and HEPES 5, pH 7.25, with $N$-methyl-D-glucamine, 300 mOsmol. Cell access was obtained using amphotericin (Sigma-Aldrich, St. Louis, MO) solubilized by sonication in DMSO $(5 \mathrm{mg} / 180 \mu \mathrm{l})$ and then diluted into $50 \mathrm{ml}$ of internal saline, which was then introduced into the plenum on the intracellular side.

Cells were voltage clamped to $-110 \mathrm{mV}$ for 3 seconds (all $\mathrm{Na}_{\mathrm{V}}$ channels except $\left.\mathrm{Na}_{\mathrm{V}} 1.5\right)$ or half a second $\left(\mathrm{Na}_{\mathrm{V}} 1.5\right)$, and sodium currents were elicited by a train of 26 depolarizations of 150 millisecond duration at $5 \mathrm{~Hz}$ to $-20 \mathrm{mV}\left(\mathrm{Na}_{\mathrm{V}} 1.1, \mathrm{Na}_{\mathrm{V}} 1.4, \mathrm{Na}_{\mathrm{V}} 1.5\right.$, $\mathrm{Na}_{\mathrm{V}} 1.6$, and $\left.\mathrm{Na}_{\mathrm{V}} 1.7\right)$ or to $0 \mathrm{mV}\left(\mathrm{Na}_{\mathrm{V}} 1.2\right.$ and $\left.\mathrm{Na}_{\mathrm{V}} 1.3\right)$ at a frequency of $5 \mathrm{~Hz}$. Cells were then left unclamped for a period of 3-8 minutes while a single concentration of test compound was added. After this compound incubation period, cells were then reclamped to $-110 \mathrm{mV}$ 
for 3 seconds (all $\mathrm{Na}_{\mathrm{V}}$ channels except $\mathrm{Na}_{\mathrm{V}} 1.5$ ) or half a second $\left(\mathrm{Na}_{\mathrm{v}} 1.5\right)$ to recover unbound channels and put through the same 26-pulse voltage protocol, as above. Peak inward current during the 26th pulse to -20 or $0 \mathrm{mV}$ in the presence of compound was divided by the peak inward current evoked by the 26 th pulse to -20 or $0 \mathrm{mV}$ in the absence of compound to determine the percentage of inhibition. Concentration-response curves of the percentage of inhibition as a function of concentration were generated to calculate $\mathrm{IC}_{50}$ values. For $\mathrm{IC}_{50}$ determination, data were fit to a four-parameter equation $(y=$ $A+\left((B-A) /\left(1+\left((x / C)^{\wedge} D\right)\right)\right)$, where $A$ is the minimum $y$ (POC) value, $B$ is the maximum $y$ (POC), $C$ is the $x$ (compound concentration) at the point of inflection, and $D$ is the slope factor). Nonlinear regression curve fitting was performed using Screener (Genedata AG, Basel, Switzerland) data analysis software.

\section{DRG Neuron Isolation}

Adult male and female C57BL/6 mice (Charles River Laboratories, San Diego, CA) were euthanized with $\mathrm{CO}_{2}$ followed by decapitation. DRGs from cervical, thoracic, and lumbar regions were removed, placed in $\mathrm{Ca}^{2+}$ and $\mathrm{Mg}^{2+}$-free Hanks' balanced salt solution (Invitrogen, Carlsbad, CA), and trimmed of attached fibers under a dissecting microscope. DRGs were sequentially digested at $37^{\circ} \mathrm{C}$ with papain (20 units/ml papain and $25 \mu \mathrm{M}$ L-cysteine included; Worthington Biochemical Corporation, Lakewood, $\mathrm{NJ}$ ) and in $\mathrm{Ca}^{2+}$ - and $\mathrm{Mg}^{2+}$-free Hanks' ( $\mathrm{pH}$ 7.4) for 20-30 minutes and then with collagenase type 2 $(0.3 \% \mathrm{w} / \mathrm{v}$, Worthington Biochemical Corporation) for 20-30 minutes. Digestions were quenched with a 1:1 mixture of Dulbecco's modified Eagle's medium and Ham's F-12 Nutrient Mixture (Invitrogen) supplemented with $10 \%$ calf serum (Invitrogen), and cells were triturated with a fire-polished Pasteur pipette prior to plating on poly-D-lysine-coated glass coverslips (Cole-Parmer, Vernon Hills, IL). Cells were maintained in a humidified incubator at $32^{\circ} \mathrm{C}$ with $5 \% \mathrm{CO}_{2}$ for $3-7$ days in the presence of $2 \%$ B27 Supplement (ThermoFisher Scientific, Waltham, MA) to increase the expression of TTX-sensitive (TTX-S) sodium channel currents.

\section{Manual Patch Clamp Electrophysiology}

DRG neurons (20-30 $\mu$ m diameter) were voltage clamped using the whole-cell patch-clamp configuration at room temperature $\left(21-24^{\circ} \mathrm{C}\right)$ using an Axopatch 200 B or MultiClamp 700 B amplifier and DIGIDATA 1322A with pCLAMP software (Molecular Devices, LLC). Pipettes, pulled from borosilicate glass capillaries (World Precision Instruments, Sarasota, FL), had resistances between 1.0 and 3.0 $\mathrm{M} \Omega$. Voltage errors were minimized using $>80 \%$ series resistance compensation. A P/4 protocol was used for leak subtraction. Voltages were uncorrected for liquid junction potentials. Currents were digitized at $50 \mathrm{kHz}$ and filtered (four-pole Bessel) at $10 \mathrm{kHz}$. Cells were lifted off the culture dish and positioned directly in front of a micropipette connected to a solution exchange manifold for compound perfusion. Cells were held at a voltage yielding approximately $20 \%$ inactivation and depolarized to $-10 \mathrm{mV}$ for 40 milliseconds every 10 seconds. The pipette solution contained the following (in $\mathrm{mM}$ ): 62.5 $\mathrm{CsCl}, 75 \mathrm{CsF}, 2.5 \mathrm{MgCl}_{2}$, 5 EGTA, and 10 HEPES, $\mathrm{pH} 7.25$ by $\mathrm{CsOH}$. The bath solution contained the following (in $\mathrm{mM}$ ): $70 \mathrm{NaCl}, 5.0 \mathrm{KCl}$, $2.0 \mathrm{CaCl}_{2}, 1.0 \mathrm{MgCl}_{2}, 10 \mathrm{HEPES}, 11$ glucose, and 140 mannitol, $\mathrm{pH} 7.4$ by $\mathrm{NaOH}$. U-2 OS cells transduced with mouse $\mathrm{Na}_{\mathrm{V}} 1.1$ or mouse $\mathrm{Na}_{v} 1.6$ BacMam viruses and human $\mathrm{Na}_{\mathrm{v}} 1.2 \mathrm{CHO}$ cells were evaluated using a voltage protocol that mimics the IonWorks Quattro protocol, as previously described (Liu et al., 2016, their Fig. 11D), in which cells are clamped to $-20 \mathrm{mV}$ to mimic the unclamped state during compound addition and incubation. For U-2 OS and CHO cells, the pipette solution contained the following (in $\mathrm{mM}$ ): $62.5 \mathrm{CsCl}$, $75 \mathrm{CsF}, 2.5 \mathrm{MgCl}_{2}$, 5 EGTA, and 10 HEPES, pH 7.25 by CsOH. The bath solution contained the following (in $\mathrm{mM}$ ): $140 \mathrm{NaCl}, 5.0 \mathrm{KCl}, 2.0$ $\mathrm{CaCl}_{2}, 1.0 \mathrm{MgCl}_{2}, 10 \mathrm{HEPES}$, and 11 glucose, $\mathrm{pH} 7.4$ by $\mathrm{NaOH}$. Data were analyzed with Clampfit and Origin Pro8 software (OriginLab, Northampton, MA).

\section{Skin-Nerve Preparation}

Methods for isolating and recording from the saphenous nerve-skin preparation were modified from those previously described (Lennertz et al., 2012; Gingras et al., 2014). Briefly, the saphenous nerve and skin from the medial dorsum of the hind paw of 2- to 3-month-old male C57BL/6 mice were rapidly dissected from the left leg. The entire nerve-skin preparation was removed and mounted in a custom-made organ bath chamber (CK Tool Company, Mountain View, CA) with corium side up. The bath was superfused at $15 \mathrm{ml} / \mathrm{min}$ with $30^{\circ} \mathrm{C}$ and oxygen-saturated synthetic interstitial fluid containing the following (in $\mathrm{mM}$ ): $123 \mathrm{NaCl}, 4 \mathrm{KCl}, 0.7 \mathrm{MgSO}_{4}, 1 \mathrm{NaH}_{2} \mathrm{PO}_{4}, 2.0 \mathrm{CaCl}_{2}, 9.5$ sodium gluconate, 10 glucose, 7.5 sucrose, and 10 HEPES, with osmolarity of $295 \mathrm{mOsm}$ and $\mathrm{pH} 7.40$ adjusted with $\mathrm{NaOH}$. The proximal end of the saphenous nerve was passed through a hole into a separate, mineral oil-filled recording chamber, desheathed, and teased into fine fibers for extracellular recordings. Receptive fields in skin were detected by light pressure with a blunt glass rod. Fiber type was determined by action potential conductance velocity after receptive field electrical stimulation with square wave pulses $(0.3-0.5$ milliseconds; 4-6 mA) delivered through a stainless steel microelectrode. Fibers with a conduction velocity less than $1.2 \mathrm{~m} / \mathrm{s}$ were classified as C-fibers.

Mechanical responses were evoked by square waves of force using a mechanical stimulator (Dual-Mode Lever Systems; Aurora Scientific, Aurora, Ontario, Canada) in ascending order of 1, 50, 100, 150, and $200 \mathrm{mN}$ (10 seconds/pulse with 300 -second interstimulus intervals) or a constant stimulation force of $150 \mathrm{mN}$ (10 seconds/pulse with 300 -second interstimulus intervals). Thermal responses were evoked by perfusion of synthetic interstitial fluid solution through two heating systems connected in series (first heater from ThermoClamp; AutoMate Scientific, Berkeley, CA; and second heater from Warner Instruments, Hamden, CT). Thermal stimuli were applied in ascending order from $30,33,38,43$, to $48^{\circ} \mathrm{C}$ (10 seconds/pulse with 300 -second interstimulus intervals) or using a constant thermal pulse $\left(48^{\circ} \mathrm{C}, 10\right.$ seconds/pulse with 300 -second interstimulus intervals).

All compounds were directly applied to a small area of the corium (dermis) side of the skin in a custom-made stainless steel ring $(5 \mathrm{~mm}$ diameter, $12 \mathrm{~mm}$ high; CK Tool Company). Two mechanical or two thermal stimuli were applied before compound treatment, and the average firing frequency from these pulses was used for the baseline. To identify fiber types as TTX-S or TTX resistant (TTX-R), $1 \mu \mathrm{M}$ TTX (Sigma-Aldrich) or $1 \mu \mathrm{M} \mathrm{Na} 1.8$ blocker [compound 31 from Kort et al. (2010)] was applied at the end of each recording. Fibers were classified as TTX-S if TTX blocked over $90 \%$ of induced action potentials, and fibers were classified as TTX-R if TTX blocked less than $90 \%$ of induced action potentials. Signals were recorded by a Neurolog System (Digitimer Limited, Letchworth Garden City, UK) and Spike 2 software (Cambridge Electronic Design Limited, Cambridge, UK). Action potentials were discriminated and counted using spike histogram software in Spike 2. Stimulus-evoked action potentials were determined by subtracting the spontaneous firing rate from the mechanical or thermal-evoked firing rate. Both recordings and analyses were performed in a blinded manner with respect to compound treatment. All data were analyzed by GraphPad Prism version 6 (GraphPad Software, La Jolla, CA) and OrigenPro 2016 (Origen Laboratory, Northampton, MA).

\section{Determination of Unbound Fraction in Plasma}

The unbound fraction $\left(f_{u}\right)$ of AMG8379 and AMG8380 was determined in mouse plasma (pooled, mixed-gender conducted in triplicate). Each compound was dissolved in DMSO and spiked into plasma at a final concentration of $5 \mu \mathrm{M}$. The resulting plasma samples were subject to ultracentrifugation and liquid chromatography-mass spectrometry analysis as described previously (DiMauro et al., 2016). AMG8379, AMG8380, and a proprietary internal standard were monitored in positive ionization mode at multiple reaction monitoring transitions of 544.1/397.2 (Q1/Q3; AMG8379 and AMG8380) and 
455.1/318.2 (Q1/Q3; internal standard), respectively. The concentration of each compound was calculated by comparing the peak areas of the test samples with those from synthetic standard curves (linear range $=0.003-100 \mu \mathrm{g} / \mathrm{ml})$. The $\mathrm{f}_{\mathrm{u}}$ values were derived as a ratio of the compound concentration in the supernatant from the ultracentrifugation samples versus the concentration in plasma samples that were stored at $4^{\circ} \mathrm{C}$ for the duration of the experiment.

\section{Mouse Pharmacokinetic and Pharmacodynamic Analyses}

To determine the pharmacokinetic properties of AMG8379 after oral administration, the compound was formulated in 2-hydroxypropyl$\beta$-cyclodextrin/water (30:70 v/v; $\mathrm{pH} 10.0)$ and dosed at 10,30 , or $100 \mathrm{mg} / \mathrm{kg}$ to 8 - to 10 -week-old male C57BL/6 or CD-1 mice (Charles River Laboratories, Wilmington, MA). Blood samples were collected and placed in $\mathrm{K}_{2}$-EDTA plasma collection tubes prior to centrifugation at 13,000 rpm for 10-15 minutes. The preparation of the plasma samples was similar to that described for the ultracentrifugation assay, except that 5 volumes $(\mathrm{v} / \mathrm{v})$ of ice-cold acetonitrile was used to precipitate plasma proteins prior to mass spectrometry analysis. Plasma samples from pharmacodynamic assays were prepared in a manner identical to that used in pharmacokinetic samples. Noncompartmental analysis was used to calculate the pharmacokinetic parameters after oral administration (Phoenix64; Cetara, Princeton, NJ).

For measurement of brain concentrations, mice were euthanized via exposure to carbon dioxide followed by the collection of brain tissue. The collected brains were homogenized using four volumes of water (v/v) containing $0.1 \%$ formic acid. Appropriate standard curves were prepared using control brain tissue from untreated mice. Six volumes of ice-cold acetonitrile containing a proprietary internal standard were added to aliquots of homogenate (test samples and standard curve). All samples were vortex mixed and centrifuged at $3000 \mathrm{rpm}$ for 15 minutes. A portion of the resulting supernatant was added to an equal volume of $0.1 \%$ formic acid in water prior to analysis by mass spectrometry, as described above. Brain/plasma ratios were calculated by comparing the absolute concentrations of the compounds in each matrix.

\section{Behavioral Experiments}

In all studies, experimental procedures were approved by the Institutional Animal Care and Use Committee of Amgen Inc. in accordance with the National Institutes of Health Guide for the Care and Use of Laboratory Animals and conducted at an AAALAC (Frederick, MD)-accredited facility. Subjects were either C57BL/6 or CD-1 male mice (Charles River Laboratories, Franklin, NY, and San Diego, CA) between the ages of 8 and 10 weeks at the beginning of each study. Animals were kept under standard temperature conditions $\left(22-24^{\circ} \mathrm{C}\right)$ and illumination (12-hour light/dark cycle with lights on at 6:30 AM). They were allowed to adjust to this environment for at least 7 days in solid-bottom cages before the experiments began and were given ad libitum access to fresh water and food. In all studies, blood samples were collected immediately after behavioral testing for pharmacokinetic analyses. Statistical analysis of behavioral data were performed via GraphPad Prism 5 software (GraphPad Software Inc., La Jolla, CA) using a one-way analysis of variance (ANOVA) to test for a drug treatment effect and followed by Dunnett's multiplecomparison post hoc tests.

\section{Open-Field Locomotor Activity in Mice}

On the day of testing, C57BL/6 male mice were orally administered either AMG8379 (10,30, or $100 \mathrm{mg} / \mathrm{kg}$ body weight) or a vehicle control formulation [2-hydroxypropyl- $\beta$-cyclodextrin/water $(30: 70 \mathrm{v} / \mathrm{v} ; \mathrm{pH}$ 10.0)] at a dose volume of $10 \mathrm{ml} / \mathrm{kg}$. Four hours after test article treatment, animals were placed into dimly lit open-field chambers $(16 \times 16$ inches; Kinder Scientific, San Diego, CA), and behavior was monitored over a 30-minute period during which locomotor activity (horizontal movement) parameters were measured in an automated manner via infrared photo-beam breaks.

\section{Histamine-Induced Scratching in Mice}

One day prior to behavioral testing, C57BL/6 male mice were anesthetized under $3 \%$ isoflurane and the area at the nape of the neck was shaved. Immediately afterward, mice were transported to the testing room and acclimated to individual sound-attenuated chambers [12 inches (length) $\times 9.5$ inches (width) $\times 8.25$ inches (height); catalog \#VFC-008 and \#NIR-022MD; Med Associates, St. Albans, VT] for 15-20 minutes. Testing was performed the following day between the hours of 8:00 AM and 3:00 PM. Four hours prior to histamine treatment, mice were orally administered AMG8379 $(10,30$, or $100 \mathrm{mg} / \mathrm{kg}$ body weight), AMG8380 (100 mg/kg), or a vehicle control formulation (2-hydroxypropyl- $\beta$-cyclodextrin/water $(30: 70 \mathrm{v} / \mathrm{v} ; \mathrm{pH}$ 10.0). A separate group of animals was orally administered the antihistamine diphenhydramine $(30 \mathrm{mg} / \mathrm{kg}$ in phosphate-buffered saline; catalog \#D3630; Sigma-Aldrich) 90 minutes prior to testing to serve as a positive control. Histamine dichloride $(8.15 \mathrm{mM}$ in a volume of $100 \mu \mathrm{L}$; catalog \#H7250; Sigma-Aldrich) was injected intradermally to the shaved area, mice were placed into the soundattenuated testing chambers, and behavior was recorded on digital video files for a period of 15 minutes. Video recordings were later reviewed, and individual scratching bouts were scored by trained experimenters. A scratching bout was defined as a rapid head tilt accompanied by a hindpaw directed at the site of intradermal injection. Termination of a scratching bout was deemed to have occurred when the hindpaw was placed back on the chamber floor or into the mouth of the animal. All dosing and scoring activities were conducted by experimenters who were fully blinded to treatment conditions.

\section{UVB-Induced Thermal Hyperalgesia in Mice}

Two days prior to thermal sensitivity testing, C57BL/6 male mice were habituated for 2 hours to the plantar test equipment (IITC Life Science, Woodland Hills, CA) and their testing chambers. Mice were placed in a Perspex cylinder 4 inches in diameter and 5 inches high atop the glass IITC testing surface, with the surface temperature set to $30^{\circ} \mathrm{C}$. Holes were drilled into the sides and top of the testing chamber to allow for adequate airflow. After habituation, mice were subject to UV irradiation. Specifically, animals were gently restrained in a cloth glove with the left plantar hind paw exposed. The area just proximal to the foot pads was treated with $200 \mathrm{~mJ} / \mathrm{cm}^{2}$ of UV irradiation with the CUP-CUBE System (MEDlight GmbH, Herford, Germany). Animals were then returned to their home cages overnight. One day prior to thermal sensitivity testing, animals were once again habituated to the IITC apparatus and testing chambers for 3 hours and then returned to their home cages overnight. On the test day, animals were placed in the testing chambers and allowed to acclimate until they were calm, typically for 90 minutes. Thermal threshold baseline measurements were then taken on the contralateral (nonirradiated, uninjured) and ipsilateral (irradiated, injured) hind paw with the IITC heat source set to an intensity level of active intensity $(\mathrm{AI})=19$. This intensity was previously calibrated to elicit an average paw withdrawal latency of 17 seconds in a nonirradiated animal. The contralateral paw withdrawal latency was always assessed first, followed by the measurement of paw withdrawal latency on the ipsilateral side. Thermal hypersensitivity was assessed using a method slightly modified from that described previously (Hargreaves et al., 1988). Briefly, the heat source was positioned under the mouse hind paw just proximal to the paw pads. Once the heat source was turned on, the latency for the animal to remove its hind paw from the stimulus was recorded as a trial. Two trials were taken per paw with an intertrial interval of at least 10 minutes. If the two trials were not within 5 seconds of each other, a third measurement was taken. An automatic cutoff latency of 30 seconds was applied to prevent tissue damage. The baseline score for each paw was defined as the average 
A
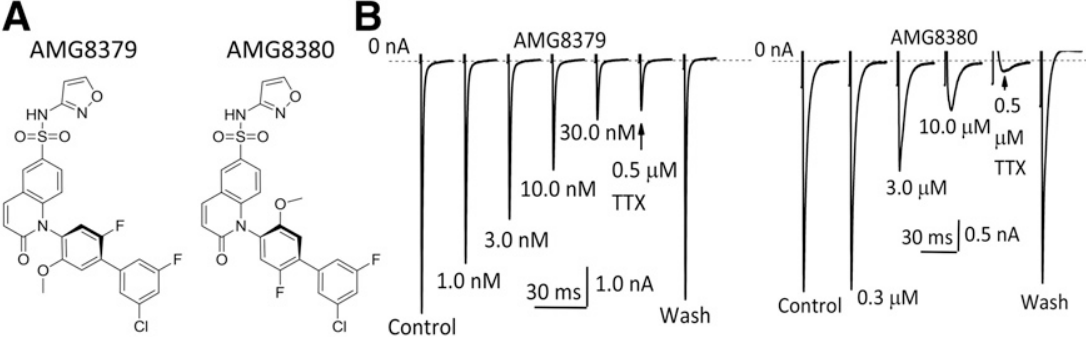

C

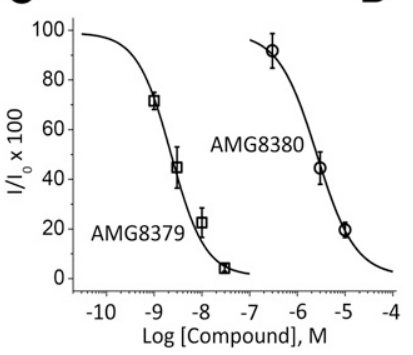

D

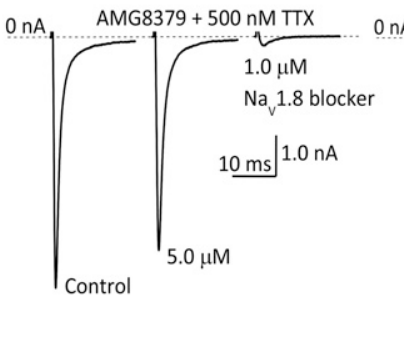

Fig. 1. Potent inhibition of TTX-S $\mathrm{Na}_{\mathrm{V}}$ channel currents by AMG8379 but not AMG8380 in mouse DRG neurons. (A) Structures of AMG8379 and AMG8380. (B) Representative whole-cell patch-clamp recordings for active enantiomer AMG8379 (left) and less active enantiomer AMG8380 (right) showing reversible block of TTX-S Nav channels. TTX was used as a positive control. (C) Dose-response curves for AMG8379 and AMG8380 on TTX-S currents. The AMG8379 IC $_{50}$ value was $3.1 \pm 0.7 \mathrm{nM}$, and AMG8380 was nearly 1000 -fold less potent with an $\mathrm{IC}_{50}$ of $2560 \pm$ $743 \mathrm{nM}(n=4-6$ neurons per compound). (D) Representative whole-cell patch-clamp recordings for active enantiomer AMG8379 (left) and less active enantiomer AMG8380 (right) showing nominal block of TTX-R currents up to $5 \mu \mathrm{M}$. Recordings were performed in the presence of $500 \mathrm{nM}$ TTX to block endogenous TTX-S currents. The positive control $\mathrm{Na}_{\mathrm{v}} 1.8$ blocker (compound 31 from Kort et al., 2010) fully blocked TTX-R currents. paw withdrawal latency (in seconds) taken by the mouse to remove its hind paw from the heat source. After baseline measurements, mice were randomized into groups by the difference score between both paws and dosed orally with AMG8379 (10, 30, or $100 \mathrm{mg} / \mathrm{kg}$ ), AMG8380 (100 mg/kg), naproxen (30 mg/kg), or 2-hydroxypropyl$\beta$-cyclodextrin/water (30:70 v/v; $\mathrm{pH} 10.0$ with $\mathrm{NaOH})$ vehicle. All dosage groups had a 4-hour pretreatment time, except for the naproxen group, which had a 2 -hour pretreatment time. During the first 2 hours after compound administration, animals were placed back into their home cages and were allowed access to food and water. Immediately after the dosing of the naproxen group, all animals were transferred to the testing chambers and allowed to reacclimatize to the testing environment. Once the pretreatment time had elapsed, the irradiated hind paw was tested as stated above. All dosing and scoring activities were conducted by experimenters who were fully blinded to treatment conditions.

\section{Capsaicin-Induced Nociception in Mice}

On the day of testing, CD-1 male mice were orally administered AMG8379 (30 or $100 \mathrm{mg} / \mathrm{kg}$ body weight), a vehicle control formulation [2-hydroxypropyl- $\beta$-cyclodextrin/water $(30: 70 \mathrm{v} / \mathrm{v} ; \mathrm{pH} 10.0)$ ], or a positive control in the form of the potent transient receptor potential cation channel subfamily V member 1 (TRPV1) antagonist AMG 517 (Doherty et al., 2007). Four hours after test article treatment (1.5 hours for AMG 517), animals were subject to intraplantar injection of $1 \mu \mathrm{g}$ of capsaicin (catalog \#M2028-50MG; Sigma-Aldrich) in a volume of $20 \mu \mathrm{l}$ of $10 \% \mathrm{EtOH} / 1 \%$ Tween-80 in phosphate-buffered saline without $\mathrm{Ca}^{2+}$ and $\mathrm{Mg}^{2+}$ (Sigma-Aldrich) into the left hind paw. Immediately after the capsaicin injection, the total time spent engaged in licking of the injected hind paw was manually recorded over a 5-minute period. All dosing and scoring activities were conducted by experimenters who were fully blinded to treatment conditions.

\section{Results}

AMG8379 Antagonist Activity. AMG8379 and AMG8380 represent a pair of atropisomeric quinolone sulfonamides discovered in our efforts to identify an isoform-selective $\mathrm{Na}_{\mathrm{V}} 1.7$ inhibitor (Fig. 1A). Discovery and optimization of drug-like properties for this chemical class is described in a separate report (Graceffa et al., 2017). AMG8379 potently inhibited recombinant human and mouse, but not rat, $\mathrm{Na}_{\mathrm{V}} 1.7$ channels expressed in heterologous HEK293 cells when evaluated by automated patch-clamp electrophysiology on a PatchXpress 7000A system using a voltage protocol where $20-50 \%$ of channels were in an inactive state (Supplemental Fig. 1; Table 1). By contrast, AMG8380 was over 100 -fold less potent on human $\mathrm{Na}_{\mathrm{V}} 1.7$ and over 20 -fold less potent on mouse $\mathrm{Na}_{\mathrm{V}} 1.7$ (Supplemental Fig. 1; Table 1). AMG8379 inhibition of human $\mathrm{Na}_{\mathrm{V}} 1.7$ was state-dependent as potency values decreased over 60 -fold when evaluated on channels in the closed/resting state (Table 1). When evaluated in mouse DRG neurons expressing endogenous $\mathrm{Na}_{\mathrm{V}} 1.7$ using manual patch clamp electrophysiology, AMG8379 potently and reversibly blocked TTX-S native channels with a mean \pm SEM $\mathrm{IC}_{50}$ of $3.1 \pm 0.1 \mathrm{nM}(n=6)$, whereas AMG8380 was nearly 1000 -fold less potent with an $\mathrm{IC}_{50}$ of $2560 \pm 743 \mathrm{nM}(n=4)$ (Fig. 1, B and C; Table 1). Neither AMG8379 nor AMG8380 blocked TTX-R channels (representing native Nav1.8 currents) in mouse DRG neurons when tested up to $5 \mu \mathrm{M}$ (Fig. 1D). AMG8379 was over 100- to 1000 -fold selective against other human and mouse $\mathrm{Na}_{\mathrm{V}}$ isoforms expressed in heterologous cells when evaluated by automated patch-clamp electrophysiology on an IonWorks Quattro system using a $5-\mathrm{Hz}$ use-dependent voltage protocol where channels are

\section{TABLE 1}

Antagonist activity of AMG8379 and AMG8380 at human, mouse, and rat $\mathrm{Na}_{\mathrm{v}} 1.7$ channels

$\mathrm{IC}_{50}$ values are expressed as mean \pm SEM. $n=$ number of replicate experiments performed.

\begin{tabular}{lcc}
\hline \multicolumn{1}{c}{ Channel } & $3078379 \mathrm{PX} \mathrm{IC}_{50}(\mu \mathrm{M})$ & $3078380 \mathrm{PX} \mathrm{IC}_{50}(\mu \mathrm{M})$ \\
\hline hNa 1.7 & $0.0085 \pm 0.025(n=9)$ & $0.907 \pm 0.372(n=8)$ \\
hNa 1.7 & $0.5216 \pm 0.075^{a}(n=3)$ & $12.92 \pm 1.36^{a}(n=3)$ \\
mNav $_{1.7}$ & $0.0186 \pm 0.0052(n=3)$ & $0.387 \pm 0.049(n=3)$ \\
rNa 1.7 & $8.61 \pm 0.242(n=3)$ & $>42(n=3)$ \\
mDRG TTX-S & $0.0031 \pm 0.0007(n=6)$ & $2.56 \pm 0.743(n=4)$ \\
mDRG TTX-R & $>5(n=2)$ & $>5(n=2)$ \\
hNa 1.5 & $>30(n=2)$ & $>30(n=2)$ \\
\hline
\end{tabular}

hNa 1.5 , human $\mathrm{Na}_{\mathrm{V}} 1.5 ; \mathrm{hNa} \mathrm{a}_{\mathrm{V}} 1.7$, human $\mathrm{Na}_{\mathrm{V}} 1.7 ; \mathrm{mDRG}$, mouse DRG; mNa 1.7 mouse $\mathrm{Na}_{\mathrm{V}} 1.7$; PX, PatchXpress; $\mathrm{rNa}_{\mathrm{V}} 1.7$, rat $\mathrm{Na}_{\mathrm{V}} 1.7$.

${ }^{a}$ Compound potency determined on the resting/closed state. 
TABLE 2

Antagonist activity of AMG8379 and AMG8380 at human and mouse $\mathrm{Na}_{\mathrm{V}}$ channels

$\mathrm{IC}_{50}$ values are expressed as mean \pm SEM. $n=$ number of replicate experiments performed.

\begin{tabular}{|c|c|c|}
\hline Channel & $3078379 \mathrm{IWQ} \mathrm{IC}_{50}(\mu \mathrm{M})$ & 3078380 IWQ $\operatorname{IC}_{50}(\mu \mathrm{M})$ \\
\hline $\mathrm{hNa}_{\mathrm{V}} 1.1$ & $>14(n=3)$ & $>14(n=3)$ \\
\hline $\mathrm{hNa}_{\mathrm{V}} 1.2$ & $2.17 \pm 0.07^{a}(n=3)$ & $>30^{a}(n=3)$ \\
\hline $\mathrm{hNa}_{\mathrm{V}} 1.3$ & $>14(n=3)$ & $>14(n=3)$ \\
\hline $\mathrm{hNa}_{\mathrm{V}} 1.4$ & $>14(n=3)$ & $>14(n=3)$ \\
\hline $\mathrm{hNa}_{\mathrm{V}} 1.5$ & $>14(n=3)$ & $>14(n=3)$ \\
\hline $\mathrm{hNa}_{\mathrm{V}} 1.6$ & $1.31 \pm 0.17(n=4)$ & $>10(n=6)$ \\
\hline $\mathrm{hNa}_{\mathrm{V}} 1.7$ & $0.0032 \pm 0.001(n=5)$ & $0.391 \pm 0.160(n=6)$ \\
\hline $\mathrm{mNa}_{\mathrm{V}} 1.1$ & $>30^{a}(n=3)$ & $>30^{a}(n=3)$ \\
\hline $\mathrm{mNa}_{\mathrm{V}} 1.6$ & $2.74 \pm 0.49^{a}(n=3)$ & $>30^{a}(n=3)$ \\
\hline $\mathrm{mNa}_{\mathrm{V}} 1.7$ & $0.0168 \pm 0.005(n=4)$ & $0.681 \pm 0.258(n=7)$ \\
\hline
\end{tabular}

hNav1.1, human Nav1.1; hNav1.2, human Nav1.2; hNav1.3, human Nav1.3; hNa 1.4 , human $\mathrm{Na}_{\mathrm{V}} 1.4 ; \mathrm{hNa}_{\mathrm{V}} 1.5$, human $\mathrm{Na}_{\mathrm{V}} 1.5 ; \mathrm{hNa}_{\mathrm{V}} 1.6$, human $\mathrm{Na}_{\mathrm{V}} 1.6$; hNa 1.7 , human $\mathrm{Na}_{\mathrm{V}} 1.7$; IWQ, IonWorks Quattro; mNa 1.1 , mouse $\mathrm{Na}_{\mathrm{V}} 1.1$; $\mathrm{mNa}_{\mathrm{V}} 1.6$, mouse $\mathrm{Na}_{\mathrm{V}} 1.6 ; \mathrm{mNa}_{\mathrm{V}} 1.7$, mouse $\mathrm{Na}_{\mathrm{V}} 1.7$.

${ }^{a}$ Compound potency determined by manual patch-clamp electrophysiology using the IWQ voltage protocol.

repetitively cycled through closed, open, and inactive states (Supplemental Fig. 2; Table 2). Using a radioligand binding assay that interrogates compound interaction with the fourth voltage sensor domain of the human $\mathrm{Na}_{\mathrm{V}} 1.7$ channel in HEK293 membranes, AMG8379 displaced a tritiated heteroaryl sulfonamide with an inhibition constant $\left(K_{\mathrm{i}}\right)$ value of $3.7 \pm 1.0 \mathrm{nM}$, similar to the $\mathrm{IC}_{50}$ value determined by electrophysiology, whereas AMG8380 displaced the label with a $K_{\mathrm{i}}$ of $167.1 \pm 74.3 \mathrm{nM}$. Thus, AMG8379 and AMG8380 represent an active and much less active pair of atropisomers that bind to the fourth voltage sensor domain of $\mathrm{Na}_{\mathrm{V}} 1.7$ and can be used to evaluate the role of $\mathrm{Na}_{\mathrm{v}} 1.7$ in specific pharmacological endpoints.

Inhibition of Mechanically Induced Action Potential Firing by AMG8379. Mechanical stimulation of afferent nerve terminals resulted in a force-dependent increase in
C-fiber action potential firing in a mouse skin-saphenous nerve preparation (Fig. 2A). Near maximal firing frequencies were obtained when receptive fields were stimulated with $150 \mathrm{mN}$ mechanical forces $(10.0 \pm 1.4 \mathrm{~Hz} ; n=25$ ) (Fig. 2B), similar to the firing frequencies reported previously (Koltzenburg et al., 1997; Hoffmann et al., 2008); therefore, $150 \mathrm{mN}$ was chosen as the mechanical stimulus for subsequent experiments with AMG8379 and AMG8380. TTX applied to the receptive field in the skin at a concentration of $1 \mu \mathrm{M}$ robustly blocked mechanically stimulated C-fiber firing (Fig. 2B) (repeated-measures two-way ANOVA, $F(1,48)=$ 33.2, $P<0.0001$ ), and TTX dose-dependently blocked C-fiber spiking with an $\mathrm{IC}_{50}$ of $15.7 \pm 0.9 \mathrm{nM}$ (Fig. 2, C and D).

AMG8379 applied to afferent nerve terminals dosedependently decreased mechanically induced C-fiber action potential firing compared with $0.1 \%$ DMSO vehicle control (Fig. 3, A and B; repeated-measures two-way ANOVA, $F(3,81)=$ $7.7, P=0.0001)$. Previously, we reported that mechanically induced C-fiber action potential firing in response to a $150 \mathrm{mN}$ stimulus in $\mathrm{Na}_{\mathrm{V}} 1.7$ knockout (KO) mice was reduced to approximately $40 \%$ of wild-type levels (Gingras et al., 2014). A similar reduction was observed with $700 \mathrm{nM}$ AMG8379 after 25 minutes (normalized firing frequency of $44.3 \pm 9.6 \%$ ) (Fig. 3B). Therefore, we calculated the $\mathrm{IC}_{50}$ for AMG8379 inhibition of C-fiber spiking based on the level of firing in $\mathrm{Na}_{\mathrm{V}} 1.7 \mathrm{KO}$ mice representing complete pharmacological block of the $\mathrm{Na}_{\mathrm{V}} 1.7$ component of this assay. In this manner, the $\mathrm{IC}_{50}$ for AMG8379 block was $47.0 \pm 8.1 \mathrm{nM}$ (Fig. $3 \mathrm{C})$. When evaluated at $470 \mathrm{nM}$, the less active enantiomer AMG8380 had a nominal effect on mechanically induced C-fiber spiking, whereas the same concentration of the active enantiomer AMG8379 blocked C-fiber spiking (Fig. 4, A and B) (repeated-measures two-way ANOVA, $F(1,44)=13.1, P=$ 0.0007). These data indicate that AMG8379 inhibition of $\mathrm{Na}_{\mathrm{V}} 1.7$ channels in afferent nerve terminals blocks mechanically induced action potential firing in C-fibers.
A

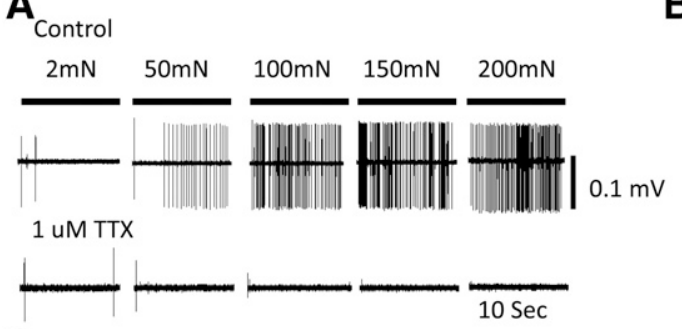

C Control $150 \mathrm{mN}, 10 \mathrm{sec}$

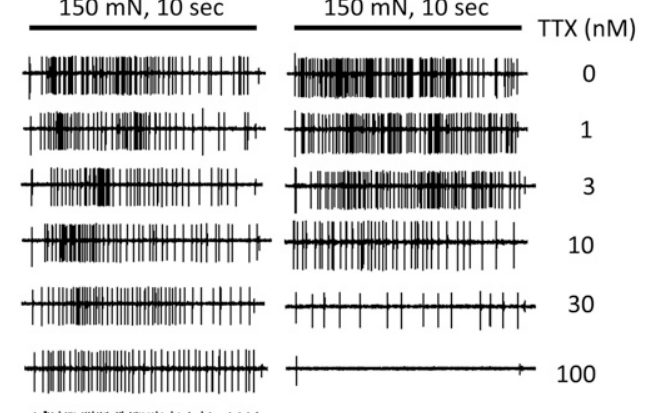

HAd
B
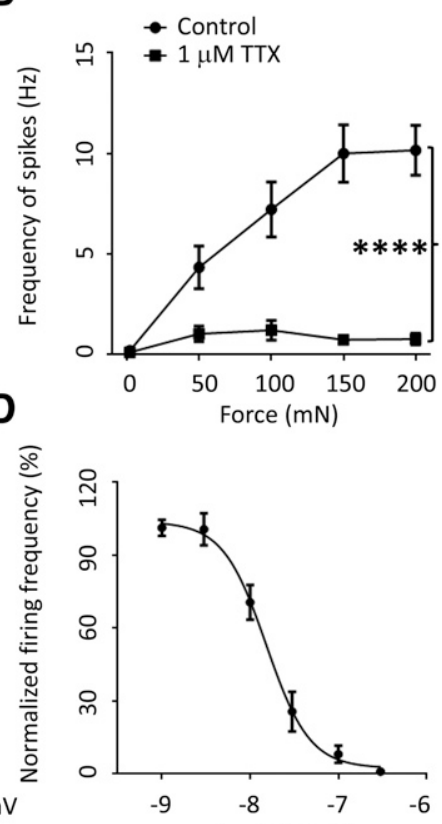

Fig. 2. Mechanically evoked action potential firing in C-fibers is blocked by TTX. (A) Representative traces for fibers treated with control $(0.1 \%$ DMSO) or TTX with the indicated force stimuli. (B) Force-response curve. Mechanically induced action potential firing was blocked by $1 \mu \mathrm{M}$ TTX. **** $P<0.0001$ by repeatedmeasures two-way ANOVA compared with control. Mean $\pm \mathrm{SEM} ; n=25$ fibers per group. (C) TTX dosedependent inhibition of mechanically evoked action potential firing in C-fibers. Mechanical stimuli were $150 \mathrm{mN}$ for 10 seconds. Representative traces for control (0.1\% DMSO; left) and TTX (right). (D) Doseresponse curve with TTX. 


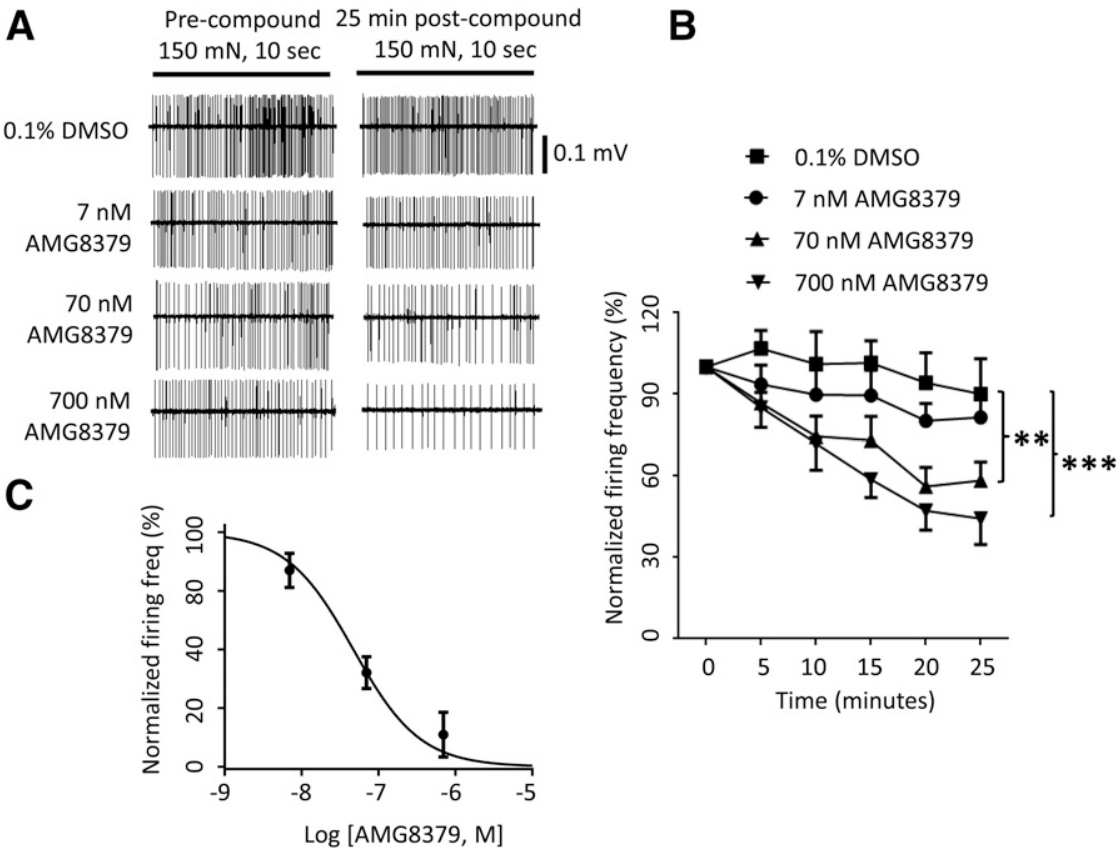

Fig. 3. Inhibition of mechanically evoked action potential firing in TTX-S C-fibers by AMG8379. (A) Representative traces at 0 and 25 minutes for $0.1 \%$ DMSO control and increasing concentrations of AMG8379. Mechanical stimuli were $150 \mathrm{mN}$ for 10 seconds every 5 minutes. (B) AMG8379 inhibition of action potential firing over time. $* * P<0.01$ *** $P<0.001$ by repeated-measures two-way ANOVA with Dunnett's multiple-comparison test compared with DMSO. Mean \pm SEM; $n=20-23$ fibers/group. (C) Dose-response curve with AMG8379 at the 25-minute time point. A baseline firing frequency of $0 \%$ was set to the level of mechanically evoked action potential firing of C-fibers reported in the $\mathrm{Na}_{\mathrm{V}} 1.7 \mathrm{KO}$ mouse (Gingras et al., 2014).
Inhibition of Thermally Induced Action Potential Firing by AMG8379. Thermal stimulation of afferent nerve terminals resulted in a temperature-dependent increase in C-fiber action potential firing in a mouse skin-saphenous nerve preparation (Fig. 5A). Near maximal firing frequencies were obtained when receptive fields were stimulated with $48^{\circ} \mathrm{C}(2.1 \pm 0.2 \mathrm{~Hz}$ after 25 minutes; $n=8)$ (Fig. 5B), similar to the firing frequencies previously reported (Kwan et al., 2009); therefore, $48^{\circ} \mathrm{C}$ was chosen as the thermal stimulus for subsequent experiments with AMG8379 and AMG8380. AMG8379 applied to afferent nerve terminals at a concentration of $470 \mathrm{nM}$ significantly decreased thermally induced C-fiber action potential firing compared with $470 \mathrm{nM}$ AMG8380 (Fig. 6, A and B) (repeated-measures two-way ANOVA, $F(1,30)=6.0, P=0.02)$. TTX applied to the receptive field in the skin at a concentration of $1 \mu \mathrm{M}$ completely blocked thermal-stimulated C-fiber firing in these fibers (normalized firing frequency of $0.9 \pm 0.3 \%$ after 25 minutes; $n=32$ ) (Fig. $6 \mathrm{~A})$. Thermal stimulation of a subset of C-fibers was not robustly blocked by $1 \mu \mathrm{M}$ TTX application. In these TTX-R fibers, $470 \mathrm{nM}$ of either AMG8379 or AMG8380 had no significant differential effect on thermally induced action potential firing (Fig. 7, A and B) (repeated-measures twoway ANOVA, $F(1,25)=0.7, P=0.3997)$. By contrast, $1 \mu \mathrm{M}$ of a
$\mathrm{Na}_{\mathrm{V}} 1.8$ selective blocker robustly suppressed thermal responses (normalized firing frequency of $4.6 \pm 2.1 \%$ after 25 minutes; $n=13$ ) (Fig. 7A). These data indicate that AMG8379 inhibition of Nav1.7 channels in afferent nerve terminals blocks thermally induced action potential firing in TTX-S C-fibers but not TTX-R C-fibers.

AMG8379 Does Not Affect Locomotor Activity in Mice. After oral dosing up to $100 \mathrm{mg} / \mathrm{kg}$, AMG8379 was restricted to the periphery with a brain-to-plasma ratio of 0.01 . To evaluate whether behavioral measurements of itch and pain in pharmacodynamic models could be confounded by nonspecific impairments of sensorimotor function, locomotor activity was monitored after oral dosing of AMG8379. As shown in Fig. 8, there was no statistically significant difference between vehicle and AMG8379 cohorts in total activity as assessed by beam breaks in an open-field arena over the 30 -minute test session (one-way ANOVA, $F(3,36)=0.06, P=$ 0.98). Thus, AMG8379 showed no evidence of adversely impacting locomotor activity, allowing for reliable and specific assessment of its effects on itch- and pain-related behaviors in mice at doses up to $100 \mathrm{mg} / \mathrm{kg}$.

Inhibition of Histamine-Induced Scratching by AMG8379. Intradermal application of histamine led to demonstrable scratching behavior in mice at the site of injection

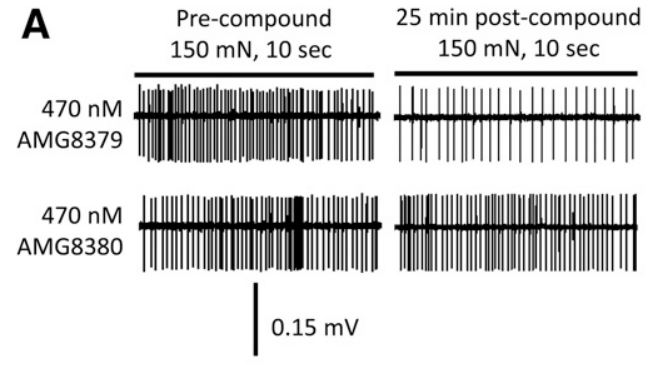

Fig. 4. Less active enantiomer AMG8380 does not block mechanically evoked action potential firing in C-fibers. (A) Representative traces for $470 \mathrm{nM}$ AMG8379 and AMG8380 at 0 and 25 minutes after compound addition. Mechanical stimuli were $150 \mathrm{mN}$ for 10 seconds every 5 minutes. (B) Inhibition of action potential firing over time by AMG8379 but not AMG8380. $* * * P<0.001$ by repeated-measures twoway ANOVA. Mean \pm SEM; $n=22-24$ fibers/group.

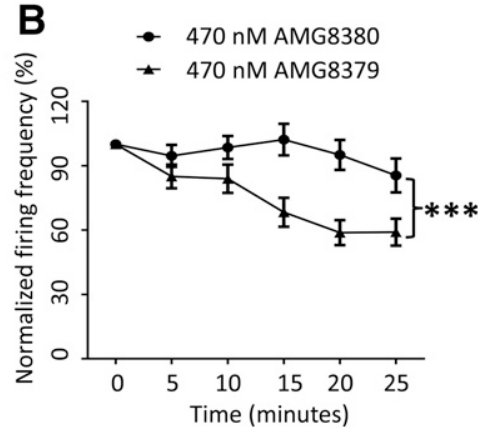




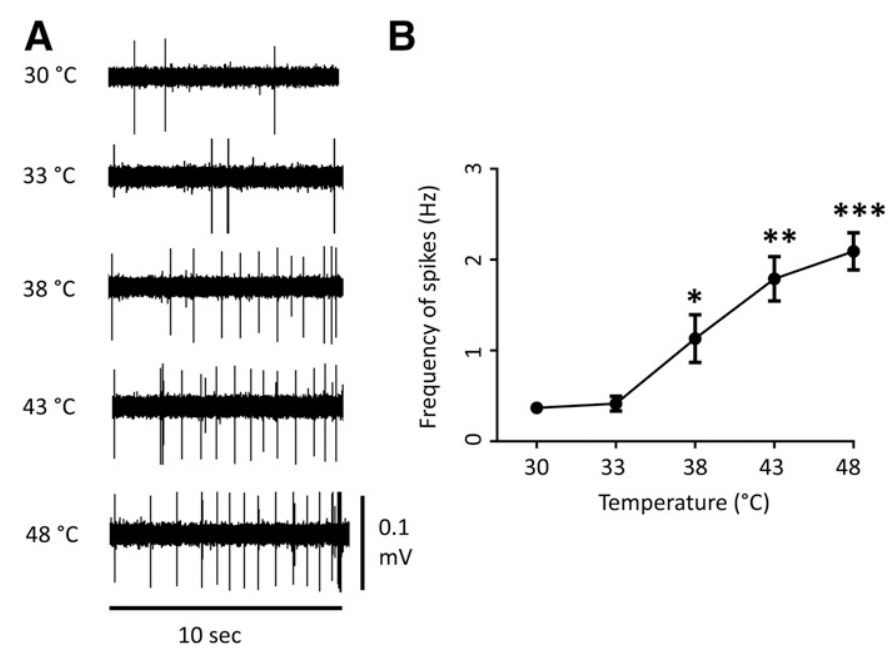

Fig. 5. Thermal-evoked action potential firing in C-fibers. (A) Representative traces for fibers incubated with solutions at the indicated temperatures. (B) Temperature-response curve. ${ }^{*} P<0.05$, $* * P<0.01$, and $* * * P<$ 0.001 by one-way ANOVA with Dunnett's multiple-comparison test compared with $30^{\circ} \mathrm{C}$. Mean $\pm \mathrm{SEM} ; n=8$ fibers per group.

that persisted over a 15-minute test period. This response could be prevented by pretreatment with a $30 \mathrm{mg} / \mathrm{kg}$ dose of the antihistamine diphenhydramine. Oral administration of AMG8379 dose-dependently blocked histamine-induced scratching behavior, with a minimal effective dose of $30 \mathrm{mg} / \mathrm{kg}$ and with a $100 \mathrm{mg} / \mathrm{kg}$ dose yielding near complete elimination of scratching bouts (Fig. 9A) (one-way ANOVA, $F(4,43)=39.7, P<0.0001$ ). By contrast, the less active enantiomer AMG8380 failed to show a statistically significant effect on scratching behavior at equivalent doses and plasma exposures to AMG8379, whereas, once again, AMG8379 produced a robust and statistically significant reduction in scratching bouts at a dose of $100 \mathrm{mg} / \mathrm{kg}$ (Fig. 9B; Table 3) (one-way ANOVA, $F(4,42)=8.0, P<0.001$; Dunnett's post hoc tests for AMG8380, $P>0.05$ for all doses and $P<0.001$ for AMG8379 compared with vehicle group).

Inhibition of UVB-Induced Thermal Hyperalgesia by AMG8379. UVB irradiation to the plantar surface of the hind paw caused thermal hyperalgesia in mice when assessed
48 hours after induction of the burn injury, as illustrated by the robust decrease in paw withdrawal latency in response to a mildly noxious heat stimulus applied to the injured (ipsilateral) paw compared with the noninjured (contralateral) paw (Fig. 10A). When animals were pretreated with the antiinflammatory agent naproxen $(30 \mathrm{mg} / \mathrm{kg})$, thermal hypersensitivity was completely reversed, with the mean withdrawal latency returning to the level associated with the nonirradiated contralateral paw. Oral administration of AMG8379 at a dose of $100 \mathrm{mg} / \mathrm{kg}$ led to an analgesic effect similar to that observed with naproxen (Fig. 10A) (one-way ANOVA, $F(5,56)=$ $6.8, P<0.0001$ ), and the mean paw withdrawal latency of the ipsilateral side was not significantly different from that of the contralateral side. Lower doses of AMG8379 (10 and $30 \mathrm{mg} / \mathrm{kg}$ ) had no significant effect on UVB-induced thermal hyperalgesia. When administered at a dose of $100 \mathrm{mg} / \mathrm{kg}$, the less active enantiomer AMG8380 did not impact paw withdrawal latencies at similar plasma exposures to those achieved with $100 \mathrm{mg} / \mathrm{kg}$ of AMG8379 (Fig. 10A; Table 3).

Inhibition of Capsaicin-Induced Nociceptive Behavior by AMG8379. Intradermal application of the TRPV1 agonist capsaicin produced a robust nociceptive response in mice, as evidenced by hind paw lifting and licking behavior that persisted over the 5-minute observation period. The potent and selective TRPV1 antagonist AMG 517 (Doherty et al., 2007) effectively blocked the capsaicin-elicited response. AMG8379 showed a dose-dependent reduction in overall nociceptive behavior, with a $100 \mathrm{mg} / \mathrm{kg}$ oral dose leading to a statistically significant reduction in total time engaged in paw licking (Fig. 10B) (oneway ANOVA, $F(3,34)=16.6, P<0.0001)$. Plasma concentration of AMG8379 at $100 \mathrm{mg} / \mathrm{kg}$ was comparable to that observed in both the histamine-induced scratch and UVB-induced thermal hyperalgesia studies (Table 3).

\section{Discussion}

AMG8379 is a potent and selective small molecule sulfonamide antagonist of human and mouse, but not rat, recombinant $\mathrm{Na}_{\mathrm{V}} 1.7$ channels in heterologous cells and native $\mathrm{Na}_{\mathrm{V}} 1.7$ channels in mouse DRG neurons. AMG8379 inhibited
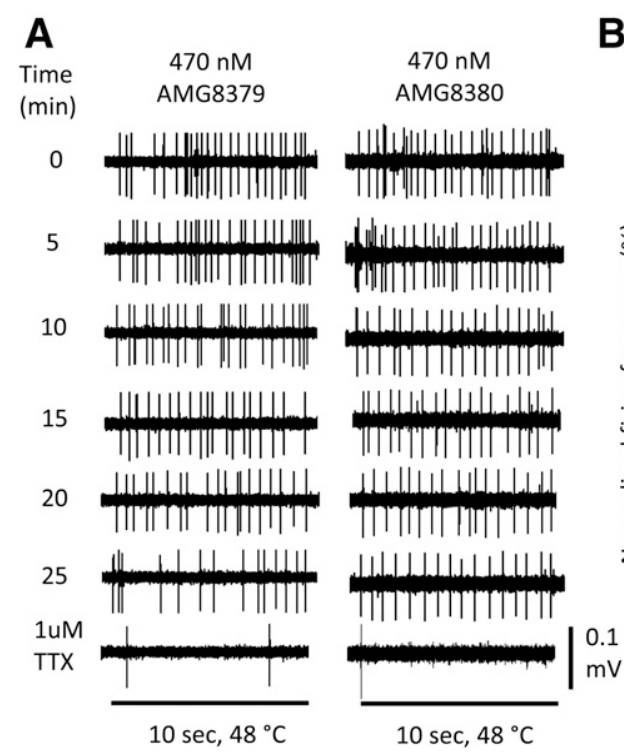

B

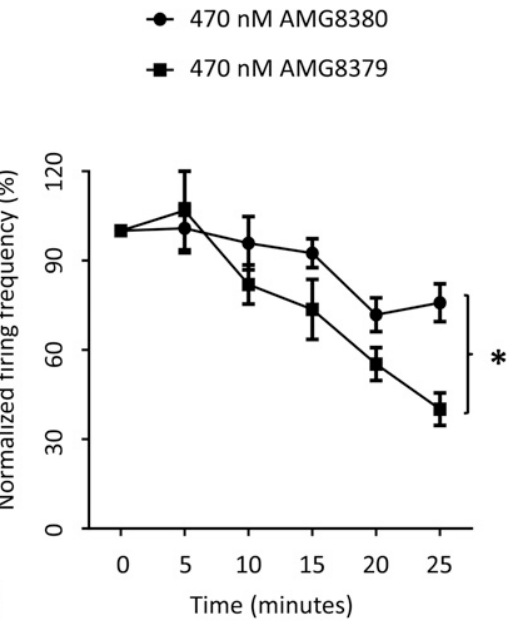

Fig. 6. Inhibition of thermal-evoked action potential firing of TTX-S C-fibers by AMG8379. (A) Representative traces for $470 \mathrm{nM}$ AMG8379 and AMG8380 over time. Thermal stimuli were $48^{\circ} \mathrm{C}$ for 10 seconds every 5 minutes. TTX completely blocked action potential firing in response to thermal stimuli. (B) Inhibition of action potential firing over time for fibers with a baseline (time zero) firing frequency $>1 \mathrm{~Hz}$ at $48^{\circ} \mathrm{C}$. $* P<0.05$ by repeated-measures two-way ANOVA compared with AMG8380. Mean \pm SEM; $n=16$ fibers/group. 


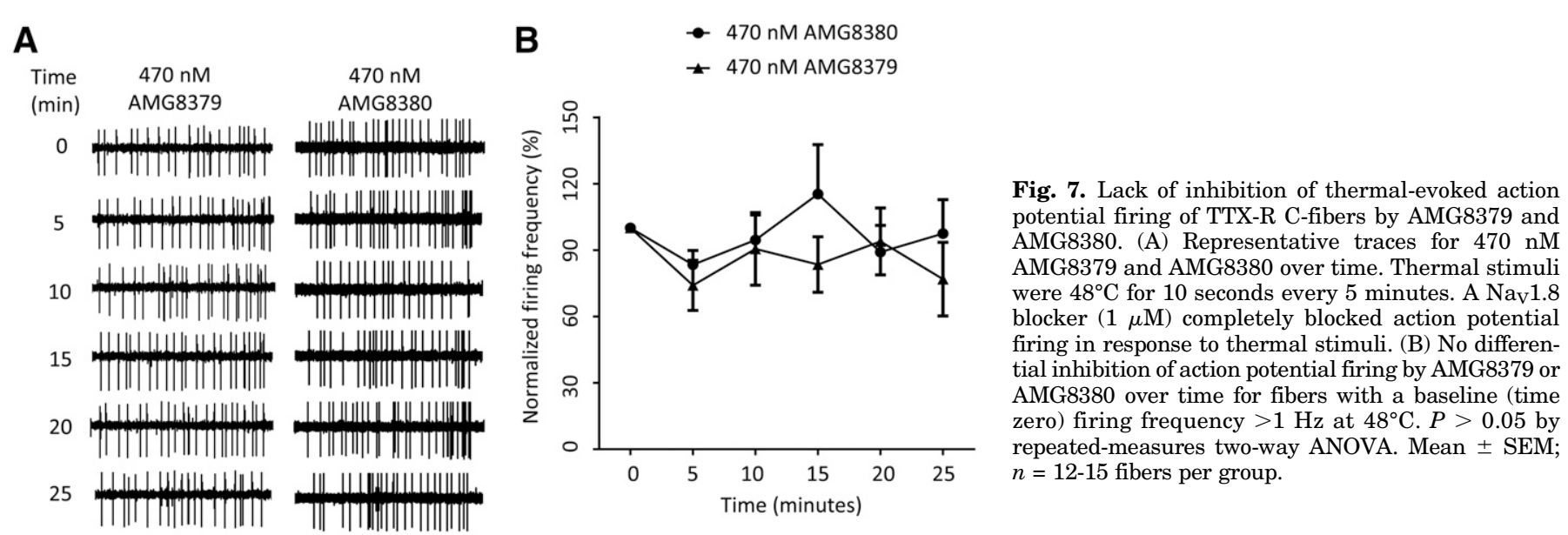

mechanically and thermally induced C-fiber action potential firing in a mouse skin-nerve preparation and blocked multiple $\mathrm{Na}_{\mathrm{v}}$ 1.7-dependent behaviors, including histamine-induced scratching, capsaicin-induced licking, and UVB-induced thermal hyperalgesia. The significantly less active atropisomer AMG8380 did not affect behavioral endpoints, pointing to a specific requirement for $\mathrm{Na}_{\mathrm{V}} 1.7$ target engagement to achieve these effects. We believe this represents the first report describing the pharmacological characterization of an active and less active $\mathrm{Na}_{\mathrm{V}} 1.7$ enantiomeric pair in a battery of in vitro, ex vivo, and in vivo experiments.

When applied to the dermal side of the skin, AMG8379 reduced $\mathrm{C}$-fiber action potential firing after both mechanical and thermal stimulation of receptive fields in ex vivo mouse skin-nerve preparation experiments. Nominal inhibition was observed with the less active atropisomer AMG8380, pointing to specific block of $\mathrm{Na}_{\mathrm{V}} 1.7$ accounting for these observations. $\mathrm{Na}_{\mathrm{V}} 1.7$ is expressed in dermal nerve fibers in human skin as well as dermal and epidermal nerve terminals in rodent skin (Black et al., 2012; Rice et al., 2015). We propose that engagement of $\mathrm{Na}_{\mathrm{V}} 1.7$ in skin nerve fibers by AMG8379 attenuates mechanically and thermally induced action potential firing. Notably, the degree of C-fiber action potential firing inhibition observed with the highest concentration of AMG8379 tested (700 nM) was similar to the residual level of C-fiber activity in preparations from $\mathrm{Na}_{\mathrm{V}} 1.7 \mathrm{KO}$ mice after mechanical stimulation (Gingras et al., 2014). Defining the level of C-fiber activity in $\mathrm{Na}_{\mathrm{V}} 1.7 \mathrm{KO}$ mice as the maximal level of $\mathrm{Na}_{\mathrm{V}} 1.7$ pharmacological block obtained in the ex vivo skin-nerve preparation, the $\mathrm{IC}_{50}$ value for AMG8379 inhibition of mechanically induced action potential firing was $47 \mathrm{nM}$, or 2.5 -fold the $\mathrm{IC}_{50}$ value of $\mathrm{mNa}_{\mathrm{V}} 1.7$ (compared with the potency on partially inactivated channels as measured on the PatchXpress platform), and a nearly full block was observed at $700 \mathrm{nM}$ AMG8379 or 38 -fold the $\mathrm{mNa}_{\mathrm{V}} 1.7 \mathrm{IC}_{50}$ value. Higher concentrations of AMG8379 required to block action potential firing in nerve fibers compared with $\mathrm{Na}_{\mathrm{V}}$ current in cultured DRG neurons or heterologous cells could be due to dermal tissue barriers that preclude compound access to $\mathrm{Na}_{\mathrm{v}} 1.7$ channels in the skin-nerve preparation and/or a requirement for few available channels in a high-resistance nerve membrane to depolarize the membrane potential to the threshold for action potential firing. AMG8379 effects were maximal after 25 minutes of incubation, which is consistent with slow diffusion through tissue and is similar to a previous report (Pinto et al., 2008) in which lower concentrations of TTX required 30-40 minutes to block nerve conduction. In hippocampal neurons, 16-fold higher levels of TTX were required to block action potential firing compared with sodium currents (Madeja, 2000). High receptor occupancy of $\mathrm{Na}_{\mathrm{V}} 1.7$ is likely required to robustly impact sensory neuron action potential firing. A small number of available $\mathrm{Na}_{\mathrm{V}} 1.7$ channels would support inward sodium currents contributing to both subthreshold ramp currents as well as the upstroke of nociceptor action potentials.

We did not evaluate higher concentrations of AMG8379 in skin-nerve studies to determine whether full block of C-fiber spiking could be achieved since we wanted to avoid potential

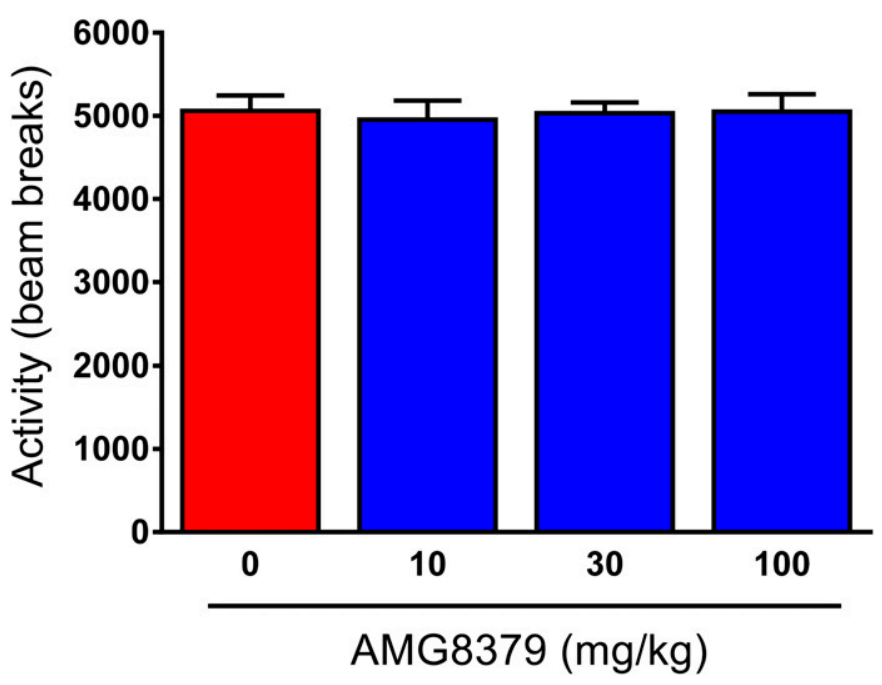

Fig. 8. AMG8379 does not affect locomotor activity in mice at doses up to $100 \mathrm{mg} / \mathrm{kg}$. Basic (horizontal) movement was quantified via automated beam break analysis over a 30 -minute period 4 hours after oral compound administration. $P>0.05$ by one-way ANOVA. Mean \pm SEM; $n=10$ per group. 

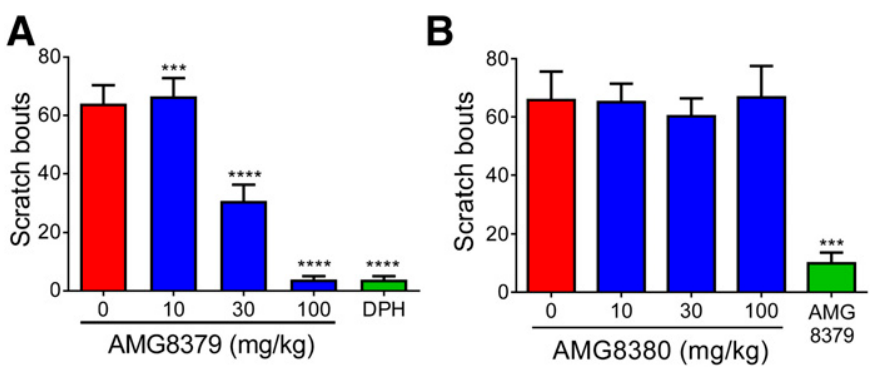

Fig. 9. Inhibition of histamine-induced scratching in mice by AMG8379 but not AMG8380. (A) Total number of scratch bouts elicited over a 15-minute test period after intradermal histamine injection. AMG8379 dose-dependently decreased scratch bouts. DPH, diphenhydramine $(30 \mathrm{mg} / \mathrm{kg})$. $* * * P<0.001, * * * * P<0.0001$ compared with vehicle-treated group; one-way ANOVA followed by Dunnett's post hoc tests; mean \pm SEM; $n=10$ for vehicle as well as AMG8379 groups and $n=8$ for DPH group. (B) Total number of scratch bouts elicited over a 15-minute test period after intradermal histamine injection. AMG8380 did not decrease scratch bouts; one-way ANOVA, $P>0.05$ compared with vehicle. AMG8379 dose $=100 \mathrm{mg} / \mathrm{kg} ; * * * P<0.001$ compared with vehicle-treated group; oneway ANOVA followed by Dunnett's post hoc tests; mean \pm SEM; $n=9-10$ for vehicle and AMG8380 groups and $n=8$ for AMG8379 group.

inhibition of non-Nav 1.7 channels. Full block of mechanically and thermally induced C-fiber spiking was obtained with TTX, indicating the presence of non-Nav1.7 TTX-S channels in these fibers. In addition to $\mathrm{Na}_{V} 1.7$ expression in smalldiameter DRG neurons whose axons correspond to C-fibers (Fukuoka et al., 2008; Fukuoka and Noguchi, 2011; Ho and O'Leary, 2011; Theriault and Chahine, 2014), the expression and function of $\mathrm{Na}_{\mathrm{V}} 1.1$ and $\mathrm{Na}_{\mathrm{V}} 1.6$ have been reported (Fukuoka et al., 2008; Zhang et al., 2013; Chiu et al., 2014; Usoskin et al., 2015). Given the lack of potent inhibition of mouse $\mathrm{Na}_{\mathrm{V}} 1.1$ and mouse $\mathrm{Na}_{\mathrm{V}} 1.6$ by AMG8379, we do not attribute inhibition of C-fiber activity to the engagement of these channels. The $\mathrm{IC}_{50}$ value for AMG3879 inhibition of mouse $\mathrm{Na}_{\mathrm{V}} 1.1$ was $>30 \mu \mathrm{M}$, and the $\mathrm{IC}_{50}$ value for AMG3879 inhibition of mouse $\mathrm{Na}_{\mathrm{V}} 1.6$ was $2.74 \mu \mathrm{M}$; these values are above the highest concentrations of AMG3879 used in skinnerve preparation experiments $(0.5-0.7 \mu \mathrm{M})$. The population of thermoresponsive C-fibers not blocked by TTX supports a critical role for TTX-R channels such as $\mathrm{Na}_{\mathrm{V}} 1.8$ in mediating action potential firing in small-diameter DRG neurons (Renganathan et al., 2001; Blair and Bean, 2002). In support of this, a Nav1.8-specific small-molecule antagonist, but not the Nav1.7-specific antagonist AMG8379, blocked thermally induced C-fiber spiking in TTX-R thermoresponsive C-fibers when tested at $1 \mu \mathrm{M}$, a concentration that is 36-fold higher than the reported $\mathrm{IC}_{50}$ value of $28 \mathrm{nM}$ on TTX-R currents in rat DRG neurons (Kort et al., 2010). We did not directly extend our analyses to A-delta or A-beta fibers, which also may express $\mathrm{Na}_{\mathrm{V}} 1.7$ (Fukuoka and Noguchi, 2011; Ho and O'Leary, 2011).

The somatosensory modalities of pain and itch induce differential behavioral responses via activation of sensory ganglia neurons expressing machinery to detect nociceptive and pruritic stimuli (Basbaum et al., 2009; Davidson and Giesler, 2010; Liu and Ma, 2011; Bautista et al., 2014). Nociceptive stimuli lead to withdrawal behavior to minimize tissue damage, whereas pruritic stimuli lead to scratching behavior to dislodge irritants. Histamine is a pruritogen that activates $\mathrm{G}$ protein-coupled receptors on primary afferents, increases intracellular calcium, and activates TRPV1 channels that lead to depolarizing receptor potentials; capsaicin is an algogen that directly gates TRPV1 channels, which lead to similar depolarizing receptor potentials (Davidson and Giesler, 2010). We propose that histamine- and capsaicininduced receptor potentials activate $\mathrm{Na}_{\mathrm{V}} 1.7$, leading to action potential initiation in primary afferent nerve fibers. We were unable to use either histamine or capsaicin as direct stimuli in skin-nerve preparation experiments due to poor responses to histamine when tested up to millimolar levels and desensitization of responses with capsaicin precluding repeated testing prepharmacological and postpharmacological challenge. The critical role of $\mathrm{Na}_{\mathrm{V}} 1.7$ in histamine-induced itch is supported by abrogation of scratching responses after intradermal histamine injection in mice with genetic deletion of $\mathrm{Na}_{\mathrm{V}} 1.7$ from birth (Gingras et al., 2014). In humans, a Nav1.7 gain-offunction mutation that decreases slow inactivation is linked to paroxysmal itch and pain attacks after environmental

TABLE 3

Terminal plasma concentrations and target coverage multiples over the $\mathrm{mNa}_{\mathrm{v}} 1.7 \mathrm{IC}_{50}\left(\mathrm{C}_{\mathrm{u}} / \mathrm{mPX} \mathrm{IC}_{50}\right)$ for AMG8379 and AMG8380 from behavioral experiments

Values in bold indicate target coverage multiples that significantly affected behavioral endpoints. Values are expressed as the mean \pm SEM.

\begin{tabular}{cccccc}
\hline Experiment & Compound & Dose $(\mathrm{mg} / \mathrm{kg})$ & Plasma $(\mu \mathrm{M})$ & Plasma $\mathrm{C}_{\mathrm{u}}(\mu \mathrm{M})$ & $\mathrm{C}_{\mathrm{u}} / \mathrm{mPX} \mathrm{IC}_{50}$ \\
\hline Open-field activity (Fig. 8) & AMG8379 & 10 & $13.7 \pm 0.766$ & $0.024 \pm 0.001$ & $1.7 \pm 0.09$ \\
& AMG8379 & 30 & $47.1 \pm 2.45$ & $0.081 \pm 0.004$ & $5.84 \pm 0.305$ \\
& AMG8379 & 100 & $189.4 \pm 13.3$ & $0.326 \pm 0.023$ & $23.5 \pm 1.65$ \\
Histamine (Fig. 9A) & AMG8379 & 10 & $10.6 \pm 1.14$ & $0.018 \pm 0.002$ & $1.32 \pm 0.141$ \\
& AMG8379 & 30 & $42.7 \pm 8.26$ & $0.073 \pm 0.014$ & $\mathbf{5 . 3} \pm \mathbf{1 . 0 3}$ \\
& AMG8379 & 100 & $174.1 \pm 7.98$ & $0.3 \pm 0.014$ & $\mathbf{2 1 . 6} \pm \mathbf{0 . 9 9}$ \\
Histamine (Fig. 9B) & AMG8380 & 10 & $5.31 \pm 0.848$ & $0.073 \pm 0.012$ & $0.18 \pm 0.030$ \\
& AMG8380 & 30 & $33.8 \pm 4.96$ & $0.466 \pm 0.068$ & $1.20 \pm 0.177$ \\
& AMG8380 & 100 & $123.2 \pm 7.92$ & $1.70 \pm 0.109$ & $4.39 \pm 0.283$ \\
& AMG8379 & 100 & $120.7 \pm 4.29$ & $0.207 \pm 0.007$ & $14.9 \pm 0.527$ \\
UVB (Fig. 10A) & AMG8379 & 10 & $25.1 \pm 5.84$ & $0.043 \pm 0.010$ & $3.11 \pm 0.723$ \\
& AMG8379 & 30 & $88.6 \pm 8.67$ & $0.153 \pm 0.015$ & $10.9 \pm 1.08$ \\
& AMG8379 & 100 & $186.0 \pm 16.1$ & $0.321 \pm 0.028$ & $\mathbf{2 3 . 1} \pm \mathbf{1 . 9 8}$ \\
& AMG8380 & 100 & $190.8 \pm 19.6$ & $2.63 \pm 0.271$ & $6.80 \pm 0.699$ \\
Capsaicin (Fig. 10B) & AMG8379 & 30 & $55.7 \pm 2.73$ & $0.096 \pm 0.005$ & $6.90 \pm 0.339$ \\
& AMG8379 & 100 & $171.1 \pm 16.2$ & $0.295 \pm 0.028$ & $\mathbf{2 1 . 2} \pm \mathbf{2 . 0 1}$ \\
\hline
\end{tabular}

$\mathrm{C}_{\mathrm{u}}$, free drug concentration; histamine, histamine-induced scratch; UVB, UVB-induced thermal hyperalgesia capsaicin, capsaicin-induced licking. AMG8379: $\mathrm{f}_{\mathrm{u}}=0.245 \% ; \mathrm{mNa}_{\mathrm{V}} 1.7 \mathrm{IC}_{50}$ (PatchXpress) $=0.0186 \mu \mathrm{M}$. AMG8380: $\mathrm{f}_{\mathrm{u}}=$ $1.38 \% ; \mathrm{mNa}_{\mathrm{V}} 1.7 \mathrm{IC}_{50}($ PatchXpress $)=0.387 \mu \mathrm{M}$. 

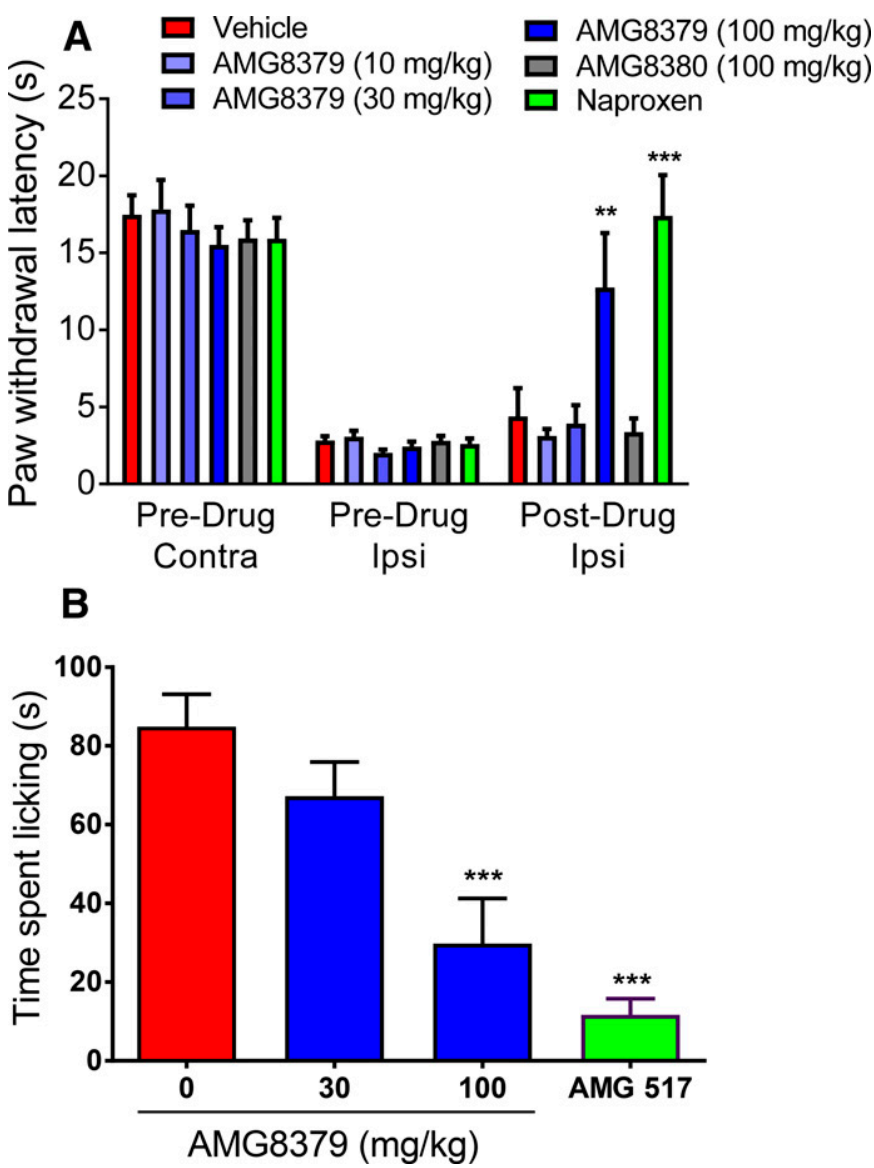

Fig. 10. AMG8379 reduced UVB-induced thermal hyperalgesia and acute capsaicin-induced nociception in mice. (A) Prior to compound treatment, paw withdrawal latency was measured for both the contralateral (contra) and ipsilateral (ipsi) hind paw in response to a thermal stimulus applied 48 hours after the induction of a localized UVB burn injury. After oral administration of AMG8379, AMG8380, naproxen (30 mg/kg), or vehicle, withdrawal latency was measured again for the ipsilateral paw. ** $P<$ 0.01 and $* * * P<0.001$ compared with the postdrug ipsilateral vehicletreated group; one-way ANOVA followed by Dunnett's post hoc tests; mean \pm SEM; $n=10$-12 per group. (B) Total time spent engaged in pawlicking behavior over a 5-minute test session in response to an intradermal injection of capsaicin. Prior to capsaicin injection, mice were orally administered AMG8379, the selective TRPV1 antagonist AMG517, or a vehicle control. *** $P<0.001$ compared with vehicle-treated group; oneway ANOVA followed by Dunnett's post hoc tests; mean \pm SEM; $n=9-10$ per group.

warmth or consumption of spicy foods, further implicating TRPV1 upstream of $\mathrm{Na}_{\mathrm{v}} 1.7$ activation (Devigili et al., 2014). In humans with loss-of-function $\mathrm{Na}_{\mathrm{v}} 1.7$ congenital insensitivity to pain mutations, pain after capsaicin chemical challenge has not been reported but would be anticipated to be deficient given the loss of thermal pain in these individuals (Cox et al., 2006; Goldberg et al., 2007). The critical role of $\mathrm{Na}_{\mathrm{V}} 1.7$ in capsaicin-induced pain behavior in mice is supported by the loss of licking responses after intradermal capsaicin injection into mice with genetic deletion of $\mathrm{Na}_{\mathrm{V}} 1.7$ from birth (unpublished data), which will be described in a subsequent report. Collectively, these data suggest that $\mathrm{Na}_{\mathrm{V}} 1.7$ is expressed both on nerve fibers dedicated to itch perception, including those responsive to histamine, as well as on TRPV1positive nerve fibers responsive to capsaicin, and that $\mathrm{Na}_{\mathrm{v}} 1.7$ function is essential for orthodromic action potential transmission toward the spinal cord.
AMG8379, a peripherally restricted molecule with nominal access to central compartments as reflected by the brain-toplasma ratio of 0.01 , robustly blocked multiple $\mathrm{Na}_{\mathrm{V}} 1.7$-dependent behavioral endpoints. Specific inhibition of histamine-induced scratching and UVB-induced thermal hyperalgesia behavior by AMG8379, but not the less active atropisomer AMG8380, indicates that antagonism of $\mathrm{Na}_{\mathrm{v}} 1.7$ in peripheral compartments is sufficient to block both itch and pain behavior in preclinical models. Robust inhibition of these behaviors in mice by AMG8379 was observed at circulating free drug plasma concentrations between 15 -fold and 23 -fold over that of the mouse $\mathrm{Na}_{\mathrm{v}} 1.7 \mathrm{IC}_{50}$ (compared with the potency on partially inactivated channels as measured on the PatchXpress platform). Importantly, at equivalent plasma exposure levels, AMG8379 did not result in any potentially confounding effects on locomotor activity in an open-field assessment. Moreover, a similar target coverage multiple was required to robustly block C-fiber action potential firing in the ex vivo skin-nerve preparation. Circulating free drug plasma concentrations of AMG8379 were only 10\% of the mouse $\mathrm{Na}_{\mathrm{V}} 1.6 \mathrm{IC}_{50}$ value, arguing that mouse $\mathrm{Na}_{\mathrm{V}} 1.6$ engagement would not account for the behavioral results observed in our pharmacodynamic studies. Notably, both the capsaicin and UVB pain models represent highly translatable models for clinical investigation with high predictability of analgesic drug development success (Oertel and Lotsch, 2013; Lotsch et al., 2014; Arendt-Nielsen et al., 2016).

Our findings are consistent with reports that poorly selective or $\mathrm{Na}_{\mathrm{V}} 1.7$-prefering small-molecule antagonists can block spontaneous or evoked pain responses in preclinical species (Brochu et al., 2006; Haroutounian et al., 2014; Matson et al., 2015; Alexandrou et al., 2016; Deuis et al., 2016; Focken et al., 2016; Frost et al., 2016; Hockley et al., 2017). Clinically, a small cohort of individuals with $\mathrm{Na}_{\mathrm{V}} 1.7$ gain-of-function mutations causing inherited erythromelalgia exhibited lower pain scores in response to thermal challenge after short-term dosing with a sulfonamide antagonist (Cao et al., 2016). A critical unanswered question in the field is whether a $\mathrm{Na}_{V} 1.7-$ selective and central nervous system-penetrant blocker, which could engage channels not only on peripheral nerve fibers but also in central terminals of primary afferent nociceptors, would translate into improved efficacy at lower doses compared with a peripherally restricted molecule (Minett et al., 2012; Dib-Hajj et al., 2013; Alexandrou et al., 2016). Our findings support the view that pharmacologic inhibition of peripheral $\mathrm{Na}_{\mathrm{V}} 1.7$ channels will translate into pain mitigation in humans. $\mathrm{Na}_{\mathrm{v}} 1.7$ antagonists currently undergoing clinical trials or in development may ultimately enable vigorous testing of this hypothesis (Emery et al., 2016).

\section{Acknowledgments}

We thank Raymond Hurst for assistance in designing initial skinnerve preparation studies, Dr. Cheryl Stucky for guidance in implementing the skin-nerve preparation technique, Chris Biorn and Jessica Able for surgical assistance with the skin-nerve preparation, Cheng Su for statistical recommendations, Min-Hwa Jasmine Lin for pharmacokinetic guidance, Melanie Cooke and Roman Shimanovich for formulation support, Paul Rose for assistance with mouse and rat $\mathrm{Na}_{\mathrm{V}} 1.7$ cell line generation, and Zaven Kaprielian for critical review of the manuscript.

\section{Authorship Contributions}

Participated in research design: Kornecook, Yin, Ilch, Lehto, Matson, Taborn, Weiss, Yu, Fremeau, and Moyer. 
Conducted experiments: Yin, Altmann, Be, Berry, Ilch, Jarosh, Johnson, Lee, Lehto, Ligutti, Liu, Luther, Matson, Ortuno, Roberts, Taborn, Wang, and Zhu.

Contributed new reagents or analytic tools: Weiss.

Performed data analysis: Kornecook, Yin, Altmann, Be, Berry, Ilch, Jarosh, Johnson, Lee, Lehto, Ligutti, Liu, Luther, Matson, Ortuno, Roberts, Taborn, Wang, Yu, Zhu, and Moyer.

Wrote or contributed to the writing of the manuscript: Kornecook, Yin, Ligutti, Liu, Luther, Yu, and Moyer.

\section{References}

Ahuja S, Mukund S, Deng L, Khakh K, Chang E, Ho H, Shriver S, Young C, Lin S, Johnson, JrJP, et al. (2015) Structural basis of Nav1.7 inhibition by an isoformselective small-molecule antagonist. Science 350:aac5464.

Alexandrou AJ, Brown AR, Chapman ML, Estacion M, Turner J, Mis MA, Wilbrey A, Payne EC, Gutteridge A, Cox PJ, et al. (2016) Subtype-selective small molecule inhibitors reveal a fundamental role for Nav1.7 in nociceptor electrogenesis, axonal conduction and presynaptic release. PLoS One 11:e152405.

Arendt-Nielsen L, Harris S, Whiteside GT, Hummel M, Knappenberger T, O'Keefe S, Kapil R, and Kyle D (2016) A randomized, double-blind, positive-controlled, 3-way cross-over human experimental pain study of a TRPV1 antagonist (V116517) in healthy volunteers and comparison with preclinical profile. Pain 157:2057-2067.

Bagal SK, Chapman ML, Marron BE, Prime R, Storer RI, and Swain NA (2014) Recent progress in sodium channel modulators for pain. Bioorg Med Chem Lett 24: $3690-3699$

Basbaum AI, Bautista DM, Scherrer G, and Julius D (2009) Cellular and molecular mechanisms of pain Cell 139.267-284.

Bautista DM, Wilson SR, and Hoon MA (2014) Why we scratch an itch: the molecules, cells and circuits of itch. Nat Neurosci 17:175-182.

Black JA, Frézel N, Dib-Hajj SD, and Waxman SG (2012) Expression of Nav1.7 in DRG neurons extends from peripheral terminals in the skin to central preterminal branches and terminals in the dorsal horn. Mol Pain 8:82.

Blair NT and Bean BP (2002) Roles of tetrodotoxin (TTX)-sensitive Na+ current, TTX-resistant $\mathrm{Na}+$ current, and $\mathrm{Ca} 2+$ current in the action potentials of nociceptive sensory neurons. J Neurosci 22:10277-10290.

Brochu RM, Dick IE, Tarpley JW, McGowan E, Gunner D, Herrington J, Shao PP, Ok D, Li C, Parsons WH, et al. (2006) Block of peripheral nerve sodium channels selectively inhibits features of neuropathic pain in rats. Mol Pharmacol 69: 823-832.

Cao L, McDonnell A, Nitzsche A, Alexandrou A, Saintot PP, Loucif AJ, Brown AR, Young G, Mis M, Randall A, et al. (2016) Pharmacological reversal of a pain phenotype in iPSC-derived sensory neurons and patients with inherited erythromelalgia. Sci Transl Med 8:335ra56.

Chiu IM, Barrett LB, Williams EK, Strochlic DE, Lee S, Weyer AD, Lou S, Bryman GS, Roberson DP, Ghasemlou N, et al. (2014) Transcriptional profiling at whole population and single cell levels reveals somatosensory neuron molecular diversity. Elife 3:e04660.

Cox JJ, Reimann F, Nicholas AK, Thornton G, Roberts E, Springell K, Karbani G, Jafri H, Mannan J, Raashid Y, et al. (2006) An SCN9A channelopathy causes congenital inability to experience pain. Nature 444:894-898.

Cummins TR, Howe JR, and Waxman SG (1998) Slow closed-state inactivation: a novel mechanism underlying ramp currents in cells expressing the hNE/PN1 sodium channel. J Neurosci 18:9607-9619.

Davidson S and Giesler GJ (2010) The multiple pathways for itch and their interactions with pain. Trends Neurosci 33:550-558.

de Lera Ruiz M and Kraus RL (2015) Voltage-gated sodium channels: structure, function, pharmacology, and clinical indications. J Med Chem 58:7093-7118.

Deuis JR, Wingerd JS, Winter Z, Durek T, Dekan Z, Sousa SR, Zimmermann K, Hoffmann T, Weidner C, Nassar MA, et al. (2016) Analgesic effects of GpTx-1, PF-04856264 and CNV1014802 in a mouse model of NaV1.7-mediated pain. Toxins (Basel) 8:78

Devigili G, Eleopra R, Pierro T, Lombardi R, Rinaldo S, Lettieri C, Faber CG, Merkies IS, Waxman SG, and Lauria G (2014) Paroxysmal itch caused by gainof-function Nav1.7 mutation. Pain 155:1702-1707.

Dib-Hajj SD, Yang Y, Black JA, and Waxman SG (2013) The Na(V)1.7 sodium channel: from molecule to man. Nat Rev Neurosci 14:49-62.

DiMauro EF, Altmann S, Berry LM, Bregman H, Chakka N, Chu-Moyer M, Bojic EF, Foti RS, Fremeau R, Gao H, et al. (2016) Application of a parallel synthetic strategy in the discovery of biaryl acyl sulfonamides as efficient and selective NaV1.7 inhibitors. J Med Chem 59:7818-7839.

Doherty EM, Fotsch C, Bannon AW, Bo Y, Chen N, Dominguez C, Falsey J, Gavva NR, Katon J, Nixey T, et al. (2007) Novel vanilloid receptor-1 antagonists: 2. Structure-activity relationships of 4-oxopyrimidines leading to the selection of a clinical candidate. J Med Chem 50:3515-3527.

Emery EC, Luiz AP, and Wood JN (2016) Nav1.7 and other voltage-gated sodium channels as drug targets for pain relief. Expert Opin Ther Targets 20:975-983.

Faber CG, Hoeijmakers JG, Ahn HS, Cheng X, Han C, Choi JS, Estacion M, Lauria G, Vanhoutte EK, Gerrits MM, et al. (2012) Gain of function Nav1.7 mutations in idiopathic small fiber neuropathy. Ann Neurol 71:26-39.

Fertleman CR, Baker MD, Parker KA, Moffatt S, Elmslie FV, Abrahamsen B Ostman J, Klugbauer N, Wood JN, Gardiner RM, et al. (2006) SCN9A mutations in paroxysmal extreme pain disorder: allelic variants underlie distinct channel defects and phenotypes. Neuron 52:767-774.

Finnerup NB, Attal N, Haroutounian S, McNicol E, Baron R, Dworkin RH, Gilron I, Haanpää M, Hansson P, Jensen TS, et al. (2015) Pharmacotherapy for neuropathic pain in adults: a systematic review and meta-analysis. Lancet Neurol 14:162-173.
Focken T, Liu S, Chahal N, Dauphinais M, Grimwood ME, Chowdhury S, Hemeon I, Bichler P, Bogucki D, Waldbrook M, et al. (2016) Discovery of aryl sulfonamides as isoform-selective inhibitors of NaV1.7 with efficacy in rodent pain models. ACS Med Chem Lett 7:277-282.

Frost JM, DeGoey DA, Shi L, Gum RJ, Fricano MM, Lundgaard GL, El-Kouhen OF, Hsieh GC, Neelands T, Matulenko MA, et al. (2016) Substituted indazoles as Nav1.7 blockers for the treatment of pain. J Med Chem 59:3373-3391.

Fukuoka T, Kobayashi K, Yamanaka H, Obata K, Dai Y, and Noguchi K (2008) Comparative study of the distribution of the alpha-subunits of voltage-gated sodium channels in normal and axotomized rat dorsal root ganglion neurons. J Comp Neurol 510:188-206.

Fukuoka T and Noguchi K (2011) Comparative study of voltage-gated sodium channel $\alpha$-subunits in non-overlapping four neuronal populations in the rat dorsal root ganglion. Neurosci Res 70:164-171.

Gingras J, Smith S, Matson DJ, Johnson D, Nye K, Couture L, Feric E, Yin R, Moyer BD, Peterson ML, et al. (2014) Global Nav1.7 knockout mice recapitulate the phenotype of human congenital indifference to pain. PLoS One 9:e105895.

Goldberg YP, MacFarlane J, MacDonald ML, Thompson J, Dube MP, Mattice M, Fraser R, Young C, Hossain S, Pape T, et al. (2007) Loss-of-function mutations in the Nav1.7 gene underlie congenital indifference to pain in multiple human populations. Clin Genet 71:311-319.

Graceffa RF, Boezio AA, Able J, Altmann S, Berry LM, Boezio CM, Butler JR, ChuMoyer MY, Cooke M, DiMauro EF, et al. (2017) Sulfonamides as selective NaV1.7 inhibitors: optimizing potency, pharmacokinetics, and metabolic properties to obtain atropisomeric quinolinone (AM-0466) that affords robust in vivo activity. J Med Chem DOI: 10.1021/acs.jmedchem.6b01850 [published ahead of print].

Hargreaves K, Dubner R, Brown F, Flores C, and Joris J (1988) A new and sensitive method for measuring thermal nociception in cutaneous hyperalgesia. Pain 32 $77-88$.

Haroutounian S, Nikolajsen L, Bendtsen TF, Finnerup NB, Kristensen AD, Hasselstrøm JB, and Jensen TS (2014) Primary afferent input critical for maintaining spontaneous pain in peripheral neuropathy. Pain 155:1272-1279.

Ho C and O'Leary ME (2011) Single-cell analysis of sodium channel expression in dorsal root ganglion neurons. Mol Cell Neurosci 46:159-166.

Hockley JR, Gonzalez-Cano R, McMurray S, Tejada-Giraldez MA, McGuire C, Torres A, Wilbrey AL, Cibert-Goton V, Nieto FR, Pitcher T, et al. (2017) Visceral and somatic pain modalities reveal $\mathrm{NaV}$ 1.7-independent visceral nociceptive pathways. J Physiol 595:2661-2679.

Hoffmann T, Sauer SK, Horch RE, and Reeh PW (2008) Sensory transduction in peripheral nerve axons elicits ectopic action potentials. J Neurosci 28:6281-6284. Holmes D (2016) The pain drain. Nature 535:S2-S3.

Klugbauer N, Lacinova L, Flockerzi V, and Hofmann F (1995) Structure and functional expression of a new member of the tetrodotoxin-sensitive voltageactivated sodium channel family from human neuroendocrine cells. EMBO J 14: $1084-1090$

Knezevic NN, Cicmil N, Knezevic I, and Candido KD (2015) Discontinued neuropathic pain therapy between 2009-2015. Expert Opin Investig Drugs 24:1631-1646.

Koltzenburg M, Stucky CL, and Lewin GR (1997) Receptive properties of mouse sensory neurons innervating hairy skin. J Neurophysiol 78:1841-1850.

Kort ME, Atkinson RN, Thomas JB, Drizin I, Johnson MS, Secrest MA, Gregg RJ, Scanio MJ, Shi L, Hakeem AH, et al. (2010) Subtype-selective Na(v)1.8 sodium channel blockers: identification of potent, orally active nicotinamide derivatives. Bioorg Med Chem Lett 20:6812-6815.

Kwan KY, Glazer JM, Corey DP, Rice FL, and Stucky CL (2009) TRPA1 modulates mechanotransduction in cutaneous sensory neurons. J Neurosci 29:4808-4819.

Lennertz RC, Kossyreva EA, Smith AK, and Stucky CL (2012) TRPA1 mediates mechanical sensitization in nociceptors during inflammation. PLoS One 7 : e43597.

Liu D, Tseng M, Epstein LF, Green L, Chan B, Soriano B, Lim D, Pan O, Murawsky CM, King CT, et al. (2016) Evaluation of recombinant monoclonal antibody SVmab1 binding to Na V1.7 target sequences and block of human Na V1.7 currents. F1000 Res 5:2764.

Liu Y and Ma Q (2011) Generation of somatic sensory neuron diversity and implications on sensory coding. Curr Opin Neurobiol 21:52-60.

Lötsch J, Oertel BG, and Ultsch A (2014) Human models of pain for the prediction of clinical analgesia. Pain 155:2014-2021.

Madeja M (2000) Do neurons have a reserve of sodium channels for the generation of action potentials? A study on acutely isolated CA1 neurons from the guinea-pig hippocampus. Eur J Neurosci 12:1-7.

Matson DJ, Hamamoto DT, Bregman H, Cooke M, DiMauro EF, Huang L, Johnson D, Li X, McDermott J, Morgan C, et al. (2015) Inhibition of inactive states of tetrodotoxin-sensitive sodium channels reduces spontaneous firing of C-fiber nociceptors and produces analgesia in formalin and complete Freund's adjuvant models of pain. PLoS One 10:e0138140.

McCormack K, Santos S, Chapman ML, Krafte DS, Marron BE, West CW, Krambis MJ, Antonio BM, Zellmer SG, Printzenhoff D, et al. (2013) Voltage sensor interaction site for selective small molecule inhibitors of voltage-gated sodium channels. Proc Natl Acad Sci USA 110:E2724-E2732.

Minett MS, Nassar MA, Clark AK, Passmore G, Dickenson AH, Wang F, Malcangio M, and Wood JN (2012) Distinct Nav1.7-dependent pain sensations require different sets of sensory and sympathetic neurons. Nat Commun 3:791.

Nassar MA, Stirling LC, Forlani G, Baker MD, Matthews EA, Dickenson AH, and Wood JN (2004) Nociceptor-specific gene deletion reveals a major role for Nav1.7 (PN1) in acute and inflammatory pain. Proc Natl Acad Sci USA 101: 12706-12711.

Oertel BG and Lötsch J (2013) Clinical pharmacology of analgesics assessed with human experimental pain models: bridging basic and clinical research. $\mathrm{Br} J$ Pharmacol 168:534-553.

Pinto V, Derkach VA, and Safronov BV (2008) Role of TTX-sensitive and TTXresistant sodium channels in Adelta- and C-fiber conduction and synaptic transmission. J Neurophysiol 99:617-628. 
Institute of Medicine (2011) Relieving Pain in America, A Blueprint for Transforming Prevention, Care, Education and Research. National Academies Press, Washington, DC.

Renganathan M, Cummins TR, and Waxman SG (2001) Contribution of $\mathrm{Na}(\mathrm{v}) 1.8$ sodium channels to action potential electrogenesis in DRG neurons. J Neurophysiol 86:629-640.

Rice FL, Albrecht PJ, Wymer JP, Black JA, Merkies IS, Faber CG, and Waxman SG (2015) Sodium channel Nav1.7 in vascular myocytes, endothelium, and innervating axons in human skin. Mol Pain 11:26.

Rush AM, Cummins TR, and Waxman SG (2007) Multiple sodium channels and their roles in electrogenesis within dorsal root ganglion neurons. J Physiol 579:1-14.

Sun S, Cohen CJ, and Dehnhardt CM (2014a) Inhibitors of voltage-gated sodium channel Nav1.7: patent applications since 2010. Pharm Pat Anal 3:509-521.

Sun S, Jia Q, Zenova AY, Chafeev M, Zhang Z, Lin S, Kwan R, Grimwood ME Chowdhury S, Young C, et al. (2014b) The discovery of benzenesulfonamide-based potent and selective inhibitors of voltage-gated sodium channel $\mathrm{Na}(\mathrm{v}) 1.7$. Bioorg Med Chem Lett 24:4397-4401.

Nightingale S (2012) The neuropathic pain market. Nat Rev Drug Disc 11:101-102. Theile JW, Fuller MD, and Chapman ML (2016) The selective Nav1.7 inhibitor, PF-05089771, interacts equivalently with fast and slow inactivated Nav1.7 channels. Mol Pharmacol 90:540-548.

Thériault O and Chahine M (2014) Correlation of the electrophysiological profiles and sodium channel transcripts of individual rat dorsal root ganglia neurons. Front Cell Neurosci 8:285.
Usoskin D, Furlan A, Islam S, Abdo H, Lönnerberg P, Lou D, Hjerling-Leffler J Haeggström J, Kharchenko O, Kharchenko PV, et al. (2015) Unbiased classification of sensory neuron types by large-scale single-cell RNA sequencing. Nat Neurosci 18:145-153.

Vetter I, Deuis JR, Mueller A, Israel MR, Starobova H, Zhang A, Rash LD, and Mobli M (2017) NaV1.7 as a pain target: from gene to pharmacology. Pharmacol Ther 172:73-100.

Weiss M, Boezio A, Boezio C, Butler JR, Chu-Moyer MY, DiMauro EF, Dineen T, Graceffa R, Guzman-Perez A, Huang H, et al. (2014), inventors, Amgen Inc., assignee. Bicyclic sulfonamide compounds as sodium channel inhibitors. International Patent Application WO 2014/201206. 2014 Dec 18.

Yang Y, Wang Y, Li S, Xu Z, Li H, Ma L, Fan J, Bu D, Liu B, Fan Z, et al. (2004) Mutations in SCN9A, encoding a sodium channel alpha subunit, in patients with primary erythermalgia. J Med Genet 41:171-174.

Zhang MM, Wilson MJ, Gajewiak J, Rivier JE, Bulaj G, Olivera BM, and Yoshikami D (2013) Pharmacological fractionation of tetrodotoxin-sensitive sodium currents in rat dorsal root ganglion neurons by $\mu$-conotoxins. $\mathrm{Br} J$ Pharmacol 169 : 102-114

Address correspondence to: Bryan D. Moyer, Amgen, Inc., One Amgen Center Drive, MS 29-2-B, Thousand Oaks, CA 91320. E-mail: bmoyer@ amgen.com 